\title{
Does Final Market Demand Elasticity Influence the Location of Export Processing? Evidence from Multinational Decisions in China*
}

\author{
Xuepeng Liu \\ Department of Economics and Finance \\ Kennesaw State University \\ xliu6@kennesaw.edu \\ Mary E. Lovely \\ Department of Economics \\ Syracuse University \\ melovely@maxwell.syr.edu \\ Jan Ondrich \\ Center for Policy Research \\ Department of Economics \\ Syracuse University \\ jondrich@maxwell.syr.edu
}

March 1, 2011

Keywords: foreign direct investment, China, wage, control-function approach

JEL Classification: F21, F23

* We thank Amil Petrin and Ken Train for a discussion of the econometric methodology. We

have benefitted from comments by Devashish Mitra, Judith Dean, and seminar participants at the 2010 AEA meetings. 


\begin{abstract}
Using data on 2884 manufacturing equity joint venture projects in China during 1993-1996, this paper estimates the importance of host wages to location choice and investigates how these decisions vary with the factor intensity of the activity and demand conditions in China's largest export market. We employ a control-function technique for conditional logit developed by Petrin and Train (2010) to find a significant, elastic response of foreign investment to wages; ceteris paribus, investors are attracted to locations with low wages. Moreover, investors involved in the most labor intensive activities exhibit the strongest response to wage differences. Using the profit function to argue that firms' ability to pass wage costs through to final markets matters for location choice, we find that investors facing more elastic demand in the US market are more sensitive to wages across export-processing locations. Taking both factor intensity and demand elasticity into account, we find that investors producing homogenous commodities, such as metals, chemicals, and food processing, are most likely to be attracted by relatively low wages. We also find that while OECD investors are more responsive to wage differences than are investors from Hong Kong, Taiwan, and Macau, they are less likely to choose a location that has received a large share of prior foreign investment.
\end{abstract}




\section{Introduction}

Better working conditions and higher wages remain elusive for millions of workers engaged in export processing throughout the developing world. While some argue that multinational firms can afford to pay higher labor costs, others claim that manufacturers at the bottom of the global supply chain compete fiercely to earn small profit margins. These small margins underlie industry claims that higher labor costs force them to shift investment to locations where wages remain low. Recent labor unrest at Chinese factories making parts for Western companies illustrates the pressures operating in the quest for higher wages and better working conditions at export-processing factories. Even as it doubled wages at its Shenzhen campus in response to harsh international attention to its labor practices, Foxconn, a Taiwanese-owned supplier to Apple, Dell, and Hewlett-Packard, repeatedly suggested that competitive conditions could necessitate moving production away from the coastal province to newer facilities in North and Central China, where wages are lower. ${ }^{1}$

Companies making goods as different as computers and sporting goods assert that they do not have the "pricing power" to absorb higher labor costs. They argue that since competition makes it impossible to pass higher costs on to their customers, they are forced to avoid locations with relatively high wages or labor-market regulation. This reasoning places final market demand conditions at the heart of location decisions for export processing. If firms are price takers in international markets, any jurisdiction that experiences increased labor costs must offer a fully offsetting differential in some form or see new investment flow to lower wage locations.

Recent estimates of final market demand elasticities, however, find that these elasticities are substantially less than infinite in many industries, suggesting that some firms' claims of having no "pricing power" are overstated. Indeed, Broda and Weinstein (2006a) estimate the elasticity of substitution across alternative sources of similar goods imported into the United States and find wide variation in the competitive conditions faced by exporters in different industries. Dividing goods into the three Rauch (1999) categories, they find that the average elasticity of substitution is much higher for

commodities than it is for reference priced goods and that the average for reference priced goods is higher 
than that for differentiated goods. These demand differences imply that firms producing outside the U.S. for the American market face varying degrees of pressure to minimize offshore production costs. Multinationals operating in industries that are imperfectly competitive may be less sensitive to wage differences across jurisdictions than those operating in highly competitive markets. In those industries where some forward shifting of costs to consumers is possible, smaller compensating differentials may be sufficient to induce firms to choose a relatively high wage location for offshore production.

Given the importance many developing countries attach to attracting new foreign investment, surprisingly little is known about the response of foreign investors to wage differences across alternative locations and what role, if any, is played by conditions in product markets. ${ }^{2}$ To avoid inappropriate pooling across countries identified by Blonigen and Wang (2005), we focus our attention on one country, China. We estimate the sensitivity of foreign investors to wage differences across Chinese provinces, accounting for industry variation in final market demand elasticities. We test whether the behavior of multinational firms investing in China reflects these competitive conditions, in addition to other factors. We posit a model in which Chinese made goods are imperfect substitutes for similar goods exported by other countries to a final (consuming) market. Foreign investors compare profits across alternative provincial locations, taking the behavior of other firms as given. In this monopolistically competitive framework, firms perceive some ability to pass higher wage costs in any one location on to consumers, with the extent of cost shifting determined by the elasticity of substitution across product varieties available in the final market. Industries facing relatively high substitution elasticities have limited ability to pass costs forward and investors in that industry are more sensitive than others to cross-provincial variation in wages when searching for production locations within China.

To measure export-market demand conditions in our empirical work, we use the Broda and Weinstein (2006a) estimates for U.S. elasticities of substitution across similar products imported from different countries. These estimates are well suited to our purpose for several reasons. First, Broda and Weinstein estimate these elasticities using an econometric procedure derived from a model of monopolistic competition that we share and which fits the Chinese setting. In this context, the 
substitution elasticity determines the firm's markup over marginal cost and, thus, is an appropriate measure of market power. Secondly, the U.S. market is the largest market for foreign invested enterprise (FIE) exports from China and, thus, American market conditions reflect important constraints on the pricing behavior of multinational firms exporting from China. Lastly, these estimates are based on thousands of observations and thus are quite precise.

A second feature of our analysis is our use of the control function in conditional logit analysis, as pioneered by Petrin and Train (2010), to address potential omitted variable bias identified in earlier studies. Applying this technique to data on 2884 manufacturing equity joint venture projects in China during 1993-1996, we find a significant, elastic response of capital to wages; ceteris paribus, investors are attracted to locations with low wages. Moreover, investors involved in the most capital intensive activities exhibit the least wage sensitivity. While controlling for the factor intensity of the industry, however, we find that demand conditions in export markets also influence location decisions. Ceteris paribus, investors in those industries where demand for Chinese made goods is most elastic are the most sensitive to wage differences. Sectors with the highest estimated average location-probability elasticity with respect to the wage include those producing homogeneous products such as iron and steel, non-ferrous metals, food processing, and chemicals. Among the least sensitive sectors are those producing differentiated products such as electrical machinery (including communication devices), professional and scientific equipment, and glass and glass products.

Because earlier literature has found evidence of significant differences in the behavior of investors from the ethnically Chinese economies (ECE) of Hong Kong, Macau, and Taiwan and the behavior of investors from other, primarily OECD, countries, we also investigate the extent to which these groups differ in their response to wages and other location characteristics. While export-market conditions and factor intensity influence both types of investors, we find that ECE investors are less responsive to wage differences and more attracted to prior investment, a finding that may be consistent with these investors' ability to access informal networks in the context of weak formal institutions. ${ }^{3}$ 
China is a suitable setting for a study of investors' responsiveness to wages. It is a large country with centralized labor-market regulation. Nonetheless, due in part to limited labor mobility, there is wide geographic variation in wages. China also provides a setting in which we are able to observe variations in behavior across industries, because foreign investment flows were large and dispersed. As Huang (2003) notes, in comparison to other countries at a similar stage of development, FDI inflows to China during the 1990s are remarkable for their wide distribution among industries and provinces. ${ }^{4}$ Finally, China is a transitional economy with a unique wage setting process for state owned enterprises (SOEs), thereby providing an excellent instrument to tackle the endogeneity problem of wages paid in the private sector.

The next section discusses the difficulties previous project-level studies of FDI have encountered in estimating investor's location-choice decisions. These studies indicate the need to control for omitted variable bias in estimation. In Section III, we model the location choice of firms engaged in export processing and we use this model to form our estimation strategy. Section IV describes the sample of foreign investment projects and measures of industry characteristics. Section V presents the results of our econometric analysis, emphasizing differences across industries and investor groups. We conclude in Section VII with a discussion of how awareness of the role of export-demand elasticity in firms' location decisions informs efforts to improve labor market conditions in developing countries.

\section{Control-Function Corrections for Omitted Attributes}

Recent studies of the distribution of aggregate FDI flows among Chinese provinces or regions include Coughlin and Segev (2000), Cheng and Kwan (2000), Fung, Iizaka, and Parker (2002), Gao (2005), and Fung, Iizaka, and Siu (2003). In all these studies, the wage is found to be a statistically significant, negative determinant of the value of FDI flowing into a Chinese province or region. With the exception of Gao (2005) this result is robust to the choice of method and to the inclusion of controls for regional skill availability. These studies based on aggregated flow data strongly support the view that firms seek locations with low wages, ceteris paribus. 
Surprisingly, studies using project-level data do not typically find wages to be a significant determinant of location choice. An insignificant wage coefficient has been estimated in studies using foreign plant locations in the United States (Ondrich and Wasylenko 1993, Head, Ries, and Swenson 1999, List and Co 2000, and Keller and Levinson 2002); in Europe (Devereux and Griffith 1998, Head and Mayer 2004); and in China (Head and Ries 1996). ${ }^{5}$ Indeed, in some specifications the estimated wage coefficient is positive. An explanation for the failure to precisely estimate a negative wage coefficient is that wages and unobserved location characteristics may not be independent, leading standard econometric techniques that require exogenous covariates to produce biased estimates. To address this issue, Liu, Lovely, and Ondrich (2010) apply a control-function approach to location-choice studies.

As proposed by Berry (1994) to explain low price elasticity estimates in differentiated product studies, sellers will receive higher prices when their product has more desirable omitted characteristics. These omitted characteristics may include any attribute that affects the true value of the product to the buyer. When independence is maintained, buyers look less price sensitive than they are because they receive more for the price they pay than the econometrician takes into account. ${ }^{6}$ Applying this logic to the FDI context, omitted location characteristics that influence worker productivity and wages could lead to biased estimates of the wage sensitivity of investors. If the unobserved factors are otherwise mean independent of observed factors, there is unambiguously a downward bias in standard estimates-firms look less sensitive to the wage than they really are.

One approach to spatially correlated errors is to estimate a nested logit model (e.g., Head and Mayer 2004). ${ }^{7}$ A second approach, which is used in both conditional logit estimation and count data methods, is to control for time invariant unobserved spatial characteristics with fixed effects (e.g., Head and Mayer 2004, Keller and Levinson 2002). ${ }^{8}$ As demanding of the data as these procedures are, neither approach fully accounts for the omission of location characteristics correlated with the wage. It is difficult to control for unobserved location specific attributes for several reasons. First, there may be insufficient variation over time or too many empty cells to use fixed effects defined over the same geographic unit as the choice set. Keller and Levinson (2002), in their study of foreign factory openings in U.S. states, Head 
and Mayer (2004), in their study of Japanese factory openings in regions within European countries, and Head and Ries (1996), in their study of FIE locations in Chinese provinces, use fixed effects defined over a geographic area larger than the unit of location choice. ${ }^{9}$ A second reason why it is difficult to control for location specific attributes is that these unobservables may vary with time. In China, where liberalization advanced at a varied pace, beginning in the coastal provinces but then pushing westward and increasing in speed, the productivity of local factors changed over time and across provinces. One way to capture such time varying unobservables is to introduce time-province fixed effects to the conditional logit. This approach typically is problematic, however, as it would introduce more than 100 additional parameters to the estimation.

An alternative two-stage method is proposed by Petrin and Train (2010) based on control functions, and further developed by Kim and Petrin (2010a). A control function is a factor added to an econometric specification to capture the effect of unobserved characteristics, thereby breaking the correlation of the wage variable with the error term of the location specific profit function. The use of control functions was pioneered by James Heckman $(1976,1979)$ to correct selectivity bias in linear regression models. The control-function approach was later used in analysis of the Tobit model by Smith and Blundell (1986) and in the analysis of the binary probit model by Rivers and Vuong (1988). Petrin and Train (2010) introduce the use of control functions to the estimation of conditional logit models.

Liu, Lovely, and Ondrich (2010) apply this control-function method to firm-location choice. Their approach proceeds in two steps: in the first step, OLS regression is used to estimate the variables that enter the control function; in the second step, the likelihood function is maximized with the control function added in the form of additional explanatory variables. They find that coefficient estimates differ significantly across the corrected and the uncorrected procedures. Using a control function, they estimate a downward bias of 50 to 90 percent in wage estimates estimated with standard techniques. We adopt this technique in our estimation procedures, as a parsimonious and powerful way to correct for potential omitted variables bias. Chen and Moore (2010) also adopt a control-function technique in their study of the location decisions of French multinational firms 


\section{The Location Choice Model}

The Profit Function

A multinational firm seeks to invest one unit of capital somewhere in China. ${ }^{10}$ The new venture will engage in processing of a differentiated good for export. ${ }^{11}$ The multinational firm compares potential profits per unit of capital across locations, taking the behavior of other firms as given, and will locate production in the province that maximizes its profit. ${ }^{12}$ The firm produces with a generalized CobbDouglas technology, using variable inputs of labor, imported intermediates, and a vector of locally provided services. Log profits for a firm producing good $g$ if it locates in province $j$ can be written as:

$$
\ln \pi_{g j}=\ln \left(1-\tau_{j}\right)+\ln \left(p_{g C}-c_{g j}\right)+\ln D_{g C},
$$

where $\tau_{j}$ reflects the (perhaps concessionary) tax rate on foreign investment in province $j, p_{g C}$ is the price on world markets of the Chinese $(C)$ variety of good $g, C_{g j}$ is the unit cost of producing good $g$ in province $j$, and $D_{g C}$ is global demand for Chinese exports of good $g$.

Let $E_{g}$ denote global expenditure on all varieties of good $g$. Consumers allocate their expenditure across varieties by maximizing an asymmetric constant elasticity of substitution subutility function for each good, as in Broda and Weinstein (2006a). ${ }^{13}$ Global demand for Chinese varieties of good $g$, which depends on prices for varieties from all producing countries, $n=1, \ldots, N$, is:

$$
D_{g C}=\frac{d_{g C} p_{g C}^{-\sigma_{g}}}{\sum_{n=1}^{N} d_{g n} p_{g n}^{1-\sigma_{g}}} E_{g}
$$

The asymmetric subutility function allows for idiosyncratic preference terms, $d_{g C}$, and resulting demand functions that differ by country of origin. ${ }^{14}$ The elasticity of substitution among varieties of good $g$ is assumed to exceed unity: $\sigma_{g}>1$.

Whichever location it chooses, the firm will set its product price to maximize profits. Following Dixit and Stiglitz (1977), if the number of firms is large, firms treat the elasticity of substitution across 
varieties, $\sigma_{g}$, as if it were the price elasticity of demand. The resulting producer prices are markups over marginal costs: $p_{g j}=\left(\sigma_{g} /\left(\sigma_{g}-1\right)\right) C_{g j}$.

To express the potential profitability of locating in province $j$, we begin by taking the natural log of (2) and substituting the resulting expression for log demand into (1). Note that when firms choose among locations in China, the only relevant information is the ordering of profits across provinces. Factors that do not vary across locations do not affect the ordering of profits and can be omitted. Subtracting these location invariant factors from profits and denoting the resulting variable profits potentially earned in province $j$ as $V_{g j}$, yields

$$
\ln V_{g j}=\ln \left(1-\tau_{j}\right)-\sigma_{g} \ln c_{g j} .
$$

Cost is a function of provincial factor prices-the wage, $w$, the price of imported intermediates, $p_{m}$, a price index for locally provided inputs, $p_{s}$ :

$$
\ln c_{g j}=\theta_{g l} \ln w_{j}+\theta_{g m} \ln p_{m j}+\theta_{g s} \ln p_{s j}
$$

where $\theta_{g k}(k=l, m, s)$ denotes a variable cost share in industry $g$. Using (3) and (4), we obtain an expression for variable profits that is decreasing in local factor prices and tax rate:

$$
\ln V_{g j}=\ln \left(1-\tau_{j}\right)-\sigma_{g} \theta_{g l} \ln w_{j}-\sigma_{g} \theta_{m} \ln p_{m j}-\sigma_{g} \theta_{s} \ln p_{s j} .
$$

It is clear from (5) that the effect on potential variable profits of a higher provincial wage, ceteris paribus: (i) is larger for firms in industries in which labor costs form a larger share of non-capital costs, $\theta_{g l}$; and (ii) is larger for firms in industries facing a higher elasticity of substitution in export markets, $\sigma_{g}$. This observation leads us to predict that both capital intensity and final market demand elasticity will influence investors' response to provincial wage differences, as evidenced by their location decisions.

\section{Agglomeration and Local Suppliers}

Previous research has shown that foreign firms have a strong tendency to locate in areas where other foreign firms have located. We incorporate agglomeration into our model by adapting the Head and 
Ries (1996) framework for localization economies. Head and Ries argue that agglomeration in China is the result of localization economies from concentrations of intermediate service providers. They assume that the market for local services is monopolistically competitive and that foreign firms use a composite of these services. They show how the equilibrium number of intermediate suppliers depends on the price of the final good, the number of foreign firms, $N_{j}^{f}$, and the number of domestic firms who may undertake the costly upgrading necessary to serve foreign firms, $\bar{N}_{j}^{s}$. Assuming log-linear functional forms, this framework allows us to derive an intermediates price index for locally provided service inputs:

$$
\ln p_{s j}=\ln A+\mu_{L} \ln w_{j}+\mu_{p} \ln p_{j}+\mu_{f} \ln N_{j}^{f}+\mu_{s} \ln \bar{N}_{j}^{s},
$$

where $A$ is a constant and the coefficients are functions of the underlying production parameters for final goods and intermediates. Substituting this expression back into the firm's profit function (5) yields an expression that can be used as the basis for estimation.

\section{Benchmark Estimating Strategy}

Our basic estimating strategy is similar to conditional logit procedures in previous studies. We treat these conditional logit results as a benchmark for comparison to results obtained using the control-

function method. The profit function (5) and the price index (6) yield a linear function for log profits with arguments given by the vector

$$
\mathbf{X}=\left[\ln w, \ln p_{m}, \ln (1-\tau), \ln N^{f}, \ln \bar{N}^{s}\right]
$$

Adding an error vector $e$ to capture firm-province idiosyncratic cost shocks, we obtain $\Pi=\mathbf{X} \boldsymbol{\beta}+e$, where $\boldsymbol{\beta}$ is the vector of parameters to be estimated. Our estimation strategy depends on the distribution of the unobserved idiosyncratic terms, $e_{i j}$. If these features are distributed independently according to an extreme value distribution, then the probability, $P_{k}$, that province $k$ is chosen, where $k$ is a member of choice set $J$, is given by

$$
P_{k}=\frac{\exp \left(\mathbf{X}_{k} \boldsymbol{\beta}\right)}{\sum_{j \in J} \exp \left(\mathbf{X}_{j} \boldsymbol{\beta}\right)} .
$$


This conditional logit is well suited to the location-choice framework since it exploits extensive information on alternatives, can account for match specific details, and allows for multiple alternatives. ${ }^{15}$ Regional fixed effects are added to the list of regressors to capture regional correlation in supply and demand shocks.

We use information on the location choices of multinational firms investing in China to estimate the sensitivity of foreign investors to wage differences. As suggested by the variable profit function (5), we expect this response to vary across industries by factor intensity and by export-market demand elasticity. To test for varying parameters, we interact the provincial wage with these two characteristics of the industry in which the Chinese based venture is engaged.

The first industry characteristic we interact with wage is capital intensity. The theoretical framework suggests that cross-provincial differences in wages are less important when local labor costs are a small share of variable production costs per unit of capital invested; that is, wage differences are less important to a more capital intensive industry. We measure capital intensity using the average wage paid by the industry in China. The average wage reflects both capital and human intensity of the activity in which workers are engaged. Data on average wages by industry is drawn from the 1995 Third Industrial Census, a complete census of formal economic activity in China. Correlation of the average wage with estimates of the 1995 capital-labor ratio is 0.71 . We prefer using the average wage rather than the measured capital-labor ratio because capital is poorly measured in 1995 and the error is likely to be correlated with the extent of state ownership. We expect that firms in industries with high average wages, and thus relatively low labor cost shares, will be less responsive to provincial wage differentials than are firms with low average wages and high labor cost shares.

The second industry characteristic we interact with the provincial wage is the elasticity of substitution across imported product varieties, estimated by Broda and Weinstein (2006a) using U.S. import data for 3-digit industries over the period 1990-2001. ${ }^{16}$ We expect that investors in an industry facing relatively high demand elasticity in export markets will be less able to shift wage costs onto consumers and, thus, will be more sensitive to provincial wage variation. 
Finally, to permit responsiveness to vary by source, we estimate conditional logits for each of three samples: the full sample, projects funded from ECE sources of Hong Kong, Macau, and Taiwan and projects funded from other, primarily OECD, sources. ${ }^{17}$ Previous work suggests that investors from Hong Kong, Macau, and Taiwan are less responsive to wage differences (Fung, Iizaka, and Siu 2003; Fung, Iizaka, Lin, and Siu 2005), a finding that may reflect technology differences or strong attachment to specific locations. Technological differences between ECE and OECD investors are consistent with the findings of Dean, Lovely, and Wang (2009), who find that ECE investors are deterred by pollution taxes while OECD investors are not. Other researchers, such as Wang (2001), emphasize the importance of local connections for the profitability of joint ventures in China, suggesting that ECE investors may be less sensitive to input cost differences across province as they choose investment locations based on geographic or personal proximity. For these reasons, we investigate the extent to which these two types of investors differ in their response to wages.

\section{The Control-Function Approach}

Despite the inclusion of regional fixed effects, possible endogeneity of the wage remains.

This fact can be illustrated by specifying the error in the profit function as a two-component error: ${ }^{18}$

$$
\varepsilon_{i j}=\beta_{\xi} \xi_{j}+e_{i j}
$$

$\xi_{j}$ is location specific, observed by workers and firms but not by the researcher. $e_{i j}$ is a firm specific idiosyncratic error, assumed to be independent across firms and locations. Defining $\mathbf{X}_{j}$ as in (8) and letting $Z_{j}$ be the instrumental variable, under certain regularity conditions the log wage can be expressed as an implicit function of all factors taken as given at the time of the decision:

$$
\ln w_{j}=\ln w_{j}\left(\mathbf{X}_{j}, Z_{j}, \xi_{j}\right)
$$

Because wages will be higher in locations with more desirable omitted characteristics, $\varepsilon_{i j}$ and $\ln w_{j}$ will be correlated even after conditioning on $\mathbf{X}_{j}$, violating the weak exogeneity requirement for conditional logit covariates and leading to inconsistent parameter estimates. 
Kim and Petrin (2010a, b) illustrate how a control function can be used to test for and correct the omitted variables problem. The method proceeds in two steps. The first step is a linear regression of $\log$ wages $\left(\ln w_{j}\right)$ on exogenous variables $\mathbf{X}_{j}$ and $Z_{j}$ using provincial level data across years. We use this regression to construct the expected wage for each province in each year. The residual is used to form the control function, $f\left(\mu_{j}, \lambda\right)$, where $\mu_{j}$ is the disturbance from the first stage regression and $\lambda$ is a vector of estimated parameters. The variable profit function for firm $i$ locating in province $j$ can now be written as $\ln \pi_{i j}=\alpha+\mathbf{X}_{i j} \beta+f\left(\mu_{j}, \lambda\right)+\left(\beta_{\xi} \xi_{j}-f\left(\mu_{j}, \lambda\right)\right)+e_{i j}$. The new error, $\eta_{i j}=\beta_{\xi} \xi_{j}-f\left(\mu_{j}, \lambda\right)+e_{i j}$, includes the difference between the actual province specific error $\beta_{\xi} \xi_{j}$ and the control function, plus the idiosyncratic error. Appendix A explains the bootstrapping methods used to correct the reported errors.

We assume that at location $j$ the log wage, $\ln w_{j}$, can be expressed as:

$$
\ln w_{j}=E\left(\ln w_{j} \mid \mathbf{X}_{j}, Z_{j}\right)+\mu_{j}\left(\xi_{j}\right),
$$

where $\mu_{j}\left(\xi_{j}\right)$ is one to one in $\xi_{j}$. Including $f\left(\mu_{j}, \lambda\right)$ in the conditional logit specification holds constant the variation in the error term of the location specific profit function that is not independent of the wage. The equation for $\ln w_{j}$ above implies that $\hat{\mu}_{j}$ can be constructed as the residual from a first stage regression of $\ln w_{j}$ on $\mathbf{X}_{j}$ and $Z_{j}$.

This approach requires an instrument for the first stage wage regression that is correlated with the wage paid by foreign invested enterprises, which are "private sector" wages, but uncorrelated with the location choices of foreign firms, conditional on other exogenous variables. As in Liu, Lovely, and Ondrich (2010), our first stage regression is a reduced form wage equation with controls for labor supply (e.g. population, share of labor force with secondary education or more) and for labor demand (e.g. the rate at which output of state owned enterprises is falling, cumulative foreign investment, and the number of local enterprises). The log of average industrial wage paid by state owned enterprises in province $j$ is used as $Z_{j}$. Liu, Lovely, and Ondrich provide justification for the assumption that private sector wages 
are influenced by provincial characteristics that drive multi-factor productivity, while SOE wages are not. They rely on the administrative SOE wage setting process and SOE productivity-wage gaps to argue for the independence of SOE wages from unobserved factors that drive foreign firm productivity. ${ }^{19}$

Figure 1 illustrates the relationship between the average SOE wage and the private wage during 1992-1995. The SOE wage tends to be high where the private wage is high, but the gap between them varies widely across provinces and regions. The figure illustrates gaps that are larger in provinces with the longest tradition of market orientation, as in the central and coastal regions, with smaller and even negative gaps in the remaining areas.

\section{Data Description and Sources}

The sample of foreign investments was compiled by Dean, Lovely, and Wang (2009). ${ }^{20}$ It was compiled from project descriptions available from the Chinese Ministry of Foreign Trade and Economic Cooperation (MOFTEC) for foreign equity joint ventures (EJVs) undertaken during 1993-1996. ${ }^{21}$

Provinces are grouped into five regions: coastal, northeast, central, southwest, and northwest. ${ }^{22}$ ECE and OECD partners engage in equity joint ventures in all provinces. Investment into the southern coastal region is predominantly ECE, reflecting the geographic proximity and early opening of these provinces. Investment in the northern coastal region is split more equally between both sources. The most prominent specialization occurs in the northwest region, where natural resource dependent activities dominate.

After China reformed its foreign investment regime in 1992, the entry of foreign investment, mostly funneled into EJVs, fueled rapid export growth. ${ }^{23}$ During the following five years of stable and liberal policy toward FDI, foreign invested enterprises contributed 32 percent of fixed asset investment by all non-state firms and accounted for more than half of Chinese manufactured exports. ${ }^{24}$ As reported by Huang (2003), working with data from the 1995 Chinese Industrial Census, foreign enterprises were dominant in export sales in a wide variety of industries, accounting for more than 50 percent of all exports in garments and footwear, leather products, sporting goods, timber processing and related products, 
furniture making, electronics and telecommunications, food processing, wood products, paper products, printing and record pressing, electric equipment, plastic products, metal products, and instruments. ${ }^{25}$

Our theoretical framework implies the use of the covariate vector $\mathbf{X}_{j}$ given by (7). Complete descriptions and sources for all variables are provided in Table 1. The Chinese Statistical Yearbook (various years) was used to compile data on labor supplies, agglomeration, intermediates suppliers, infrastructure and incentives. Summary data for provincial characteristics are provided in Table 2.

The provincial private wage is measured by the average annual wage paid by private and foreign enterprises, drawn from Branstetter and Feenstra (2002). We also draw from Branstetter and Feenstra the average annual wage paid by state owned enterprises in each province, which we use as a first stage instrument. ${ }^{26}$ Wage measures are deflated by a national price deflator to create an average annual real provincial wage. Average wages do not control for provincial variation in labor quality, so we also include in the conditional logit analysis the share of the provincial labor force that has completed senior secondary school or above.

We do not have direct measures of the cost of imported inputs $\left(p_{m}\right)$ nor the corporate tax rate $(\tau)$. To control for provincial variation in these factors, we include an incentive dummy that takes a value of one if there is a special economic zone (SEZ) or open coastal city (OCC) in the province. This variable does not vary during the 1993-1996 period. We also include a measure of provincial infrastructure, which influences the local cost of imported inputs. Infrastructure is proxied by the number of urban telephone subscribers relative to population. The number of foreign firms $\left(N^{f}\right)$ is measured as the real value of cumulative FDI, which we refer to as agglomeration, for the period 1983 to the year before the project is undertaken. Availability of potential suppliers of intermediate goods $\left(\bar{N}_{S}\right)$ is measured by the number of domestic firms, defined as the total number of domestic enterprises at the township level and above (thereby capturing larger enterprises that may have the capacity to supply a foreign invested plant).

To control for potential local market demand, we include the population of the province and several measures of provincial income. The income measure is the size of the provincial private market, 
calculated as the private share of output multiplied by provincial GDP. We use non-state output to gauge the size of the market open to foreign enterprises because domestic sales in a province will be limited if demand is substantially satisfied by the state sector. Additionally, to allow for a flexible form for this market measure, we include the square of this variable. Sales may also be affected by the extent to which a province is liberalizing, so we include the change in state ownership, measured as the difference in the share of industrial output produced by SOEs between time $t-1$ and time $t$.

\section{Results}

We begin by estimating the conditional logit for the sample of all investors, for ECE investors alone, and for OECD investors alone. Our results support the use of the control function to address endogeneity concerns. They also indicate that ECE and OECD investors place different weights on the wage and other provincial characteristics when choosing an investment location. After discussion of these benchmark results, we re-estimate the model, allowing wage sensitivity for each group to vary with industry characteristics.

\section{Investor Group Heterogeneity: Control-Function Results}

Table 3 reports the results of conditional logit estimation, for the full sample, the ECE subsample, and the OECD subsample. All variables are lagged one year to represent predetermined information, available to investors at the time of the location decision. Models (1), (2), and (3) provide results estimated with inclusion of the control function as well as regional fixed effects for the full sample and both subsamples. The overall fit of the equation is good and comparable to prior studies using similar procedures (e.g. Head and Mayer 2004). The estimated coefficient for the residual from the first stage wage regression is positive and significant at the 1 percent level for the full sample and each subsample. The reported standard errors (as well as variance matrices used in the testing of joint hypotheses) were corrected using a bootstrapping technique described in the appendix. The appendix also provides the first stage regression results. This regression explains 86 percent of the variation in the private wage and the 
coefficient of the log of the SOE wage is highly significant, with a $t$-statistic of 9.07. Adding the log of the SOE wage to the first stage explains an additional 5 percent of the variation in private wages.

Kim and Petrin (2010b) interpret the significance of the control function as a test for omitted variable bias. The significance of the residual, therefore, indicates the presence of omitted variable bias in the uncorrected estimates. The estimated wage coefficient is substantially larger in absolute value when we include the control function than the estimate we obtain without its use, as seen in comparison models (4), (5), and (6) This comparison provides an estimate of the downward bias in the standard method, consistent with findings reported in Liu, Lovely, and Ondrich (2010). The coefficient of -2.079 estimated with the control function for the full sample is more than twice as large in absolute value as the coefficient of - 0.949 estimated without the control function. The estimated coefficient for ECE investors increases from -0.66 to -1.72 when the control function is added, while for OECD investors it increases from -1.79 to -2.94 . All remaining covariates have the expected signs, are highly significant even in the presence of regional fixed effects, and are unchanged by the addition of the control function. ${ }^{27}$

As shown in the second and third models of Table 3, the probability of an ECE or an OECD investor locating in a given province is negatively affected by the provincial wage and this response is highly significant for both groups. The coefficient estimate for the OECD sample, however, is larger than it is for the ECE sample, suggesting that although both types of investors respond to wage differences, the OECD sample appears to be more responsive, ceteris paribus. Indeed, the elasticity of the probability of locating in a given province with respect to a unit decrease in its log wage is 72 percent higher for OECD investors than for ECE investors. OECD investors' lack of family and business ties to specific provinces may allow these investors to be more sensitive to differences in production costs when choosing a location. The clustering of Chinese funded overseas export activities, rather than being evidence of single minded attraction to low wage havens, as it is often depicted, may instead be explained by an expectation of personal connections to protect and promote business interests. ${ }^{28}$

Observed clustering by ECE investors may also reflect a heavy weight placed on proximity to related investments and to the source country. Evidence consistent with either view is the larger weight 
placed by ECE investors on past investment, indicative of production clusters: the estimating coefficient for the agglomeration measure is 0.522 for ECE investors but less than sixty percent of that magnitude, 0.298, for OECD investors, both estimates highly significant. The probability of locating in a given province with respect to a one unit increase in log agglomeration is 43 percent less for OECD investors than for ECE investors. ECE investors also place a lower weight on the presence of local firms who may be potential local suppliers (their elasticity is 42 percent higher). ECE investors are somewhat more likely than OECD investors to locate in the coastal and central provinces, closer to their sources, and less likely to locate in the northwest. They are also less sensitive to the skilled labor share in the province, and designation of the province as an SEZ or OCC, all consistent with the view that these investors have access to networks and local connections perhaps not accessed by OECD investors.

These findings differ from inferences drawn from econometric analyses of regional FDI inflows that distinguish investors by source. Fung, Iizaka, Lin, and Siu (2005), who estimate a random effects model using regional data from 1990-1999, find that Hong Kong investment flows are more sensitive to local labor costs than are flows from the United States. The authors ascribe the observed difference in behavior to clustering by U.S. owned firms in capital intensive sectors and to the export-processing focus of Hong Kong owned enterprises. Fung, Iizaka, and Siu (2003) compare Japanese and Hong Kong flows into Chinese regions and also find that Hong Kong investment is more sensitive to wage differences. Our results, based on project-level data and conditional logit analysis, do not support this characterization of differences in behavior. Rather, our findings suggest that OECD investors weight local wages more heavily than do ECE investors, at least at the time that the host province is chosen. We now turn to additional analysis that allows for differences along industrial characteristics, including factor intensity.

\section{Allowing for Differences in Export-Market Demand and Capital Intensity}

To investigate how wage sensitivity is conditioned by industry characteristics, we interact the provincial wage with measures of factor intensity and export-market conditions. Based on our previous findings supporting its use, we estimate these conditional logits using a control function approach. Results are shown in Table 4. 
Because previous research suggests that differences among investors in wage sensitivity may be explained by differences in the factor intensity of their projects, we proceed by first introducing an interaction of the provincial wage with a measure of the industry's capital intensity, expecting a less elastic response from investors whose Chinese ventures are more capital intensive. The first three models of Table 4 provide little support for the contention that attraction to low wages is a function of factor intensity. The interaction of log provincial wage and industry capital intensity is positive, as expected, but not significantly significant, for the full sample and for each subsample. ${ }^{29}$ Other inferences are not affected by the inclusion of the interaction term.

Because these models include interactions involving the wage, we form the control function by including interactions between the first stage residual and the industrial characteristic. Testing whether the related coefficients are all zero requires a joint hypothesis test. We present the value of the Wald $\chi^{2}$ in the row labeled "CF Wald Statistic." The Wald Statistic is significant at the 5 percent level in all three samples. These results reinforce the indication of omitted variable bias present in the models that omit the control function.

To explore the hypothesis that export-market conditions influence firms' wage sensitivity, we also interact the provincial wage with a measure of demand elasticity, the Broda-Weinstein (2006a) elasticities of substitution estimated for the U.S. import market. ${ }^{30}$ These demand elasticities are shown in Table 5 for each industry. There is a positive correlation between the capital-intensity measure and the Broda-Weinstein elasticities - more capital-intensive industries face more elastic market conditions, in part because these industries tend to produce homogeneous commodities. Because high capital intensity is predicted to reduce wage sensitivity while elastic market demand raises it, by not accounting explicitly for the demand elasticity, we may incorrectly infer that factor intensity does not matter for wage sensitivity. This explains why we obtain insignificant coefficients for the wage-interaction terms in the first three columns of Table 4. 
Following our theoretical model, we expect the coefficient on an interaction of the wage and the demand elasticity to be negative-a higher price elasticity reduces the ability to shift higher wage costs to consumers and makes investors more sensitive to provincial wage variation. We control for both factor intensity and demand elasticity simultaneously. As shown in the last three columns of Table 4, the wage and both wage-interaction terms have the expected signs and are highly significant for all three samples. A higher demand elasticity is associated with a greater aversion to high wage provinces: for the full sample, the estimated coefficient on the interaction of wage and demand elasticity is -0.368 and highly significant. This result is consistent with the hypothesis that firms facing more competitive conditions in export markets are less able to absorb higher wages by passing them to customers. We also find that more capital intensive industries are less sensitive to the wage: for the full sample, the estimated coefficient on the wage-factor intensity interaction is 0.371 and highly significant.

When the sample is split into investor groups, as shown in the fifth and sixth models, capital intensity reduces wage sensitivity for both groups, but more so for OECD investors. Export-demand conditions are significant influences on wage sensitivity for both groups but the estimated coefficient for the OECD sample is larger than it is for the ECE sample, -0.431 versus -0.339 . As in the models without wage-interaction terms, we find that ECE investors place a higher weight on prior investment, but a lower weight on local firms, the skilled labor share, and designation of the province as an SEZ or OCC than do foreign investors.

We find that OECD investors are more responsive to wage differences than ECE investors, controlling for industrial variation in behavior. At the mean capital intensity and mean demand elasticity, the wage coefficient for OECD investors is -2.01 , while for ECE investors it is -0.76 . The estimated wage coefficient for OECD investors in footwear, the least capital intensity industry, is -2.46 , compared to an estimate of -1.06 for ECE investors. Again, these estimates are precisely estimated. Differences between the two groups widen as the capital intensity of the industry rises. For example, the wage coefficient for the most capital intensive activity, petroleum refining, is more than four times larger for OECD investors (-1.26) than for ECE investors (-0.29). Thus, differences in investor group behavior do 
not merely reflect differences in the sectoral composition of their foreign activities.

Foreign investment typically flows into particular sectors, shifting the pattern of production toward these favored sectors. To consider how shifts in production composition might change the elasticity of demand for domestic labor, we calculate the average estimated own-wage elasticities for each industry, for both the ECE and the OECD samples, as shown in Table 5, using estimated coefficients from Table 4. Comparing the last two columns, we see that the OECD elasticity is larger than the ECE elasticity for every industry, but both subsamples produce a similar ranking across industries. Some interesting comparisons across industries emerge when we look at these rankings. In the mid 1990s, industries with large shares of total exports are among those industries with above average responsiveness to wage differences, a finding consistent with their rapid movement into China after the liberalization of

FDI rules in 1992. ${ }^{31}$ These industries include footwear, wood products, textiles, and food. However, over the following decade, Chinese exports grew strongly in sectors with below average wage responsiveness, particularly professional, scientific, and controlling equipment, electrical machinery, and non-electrical machinery. That China was able to shift its export profile so quickly away from labor intensive sectors toward sectors that are less responsive to wage differences is worthy of further study.

\section{Wage Elasticities, By Province}

There is some concern, well expressed by Chan (2003), that coastal provinces maintain low wages for foreign employers to fend off competition for FDI from interior provinces. Our estimates shed some light on how much power an individual province has to engage in this form of "wage competition." Table 6 provides estimated own-wage and cross-wage probability elasticities, by province, calculated using the estimates in Table 4. The elasticities of province $j$ are calculated by $\sigma_{j}^{o w n}=\beta^{w}\left(1-P_{j}\right)$ and $\sigma_{j}^{\text {cross }}=-\beta^{w} P_{j}$ where $\beta^{w}$ and $P_{j}$ are the estimated wage coefficient and predicted probability that an investor chooses province $j$ (see Greene 2003). Looking across locations, the own-wage elasticity is smallest for those provinces with the highest predicted probability of being chosen, including Beijing, Guangdong, Jiangsu, and Shandong. These provinces, conversely, have the largest predicted cross-wage 
effects, implying that a decrease in their wage has a larger effect on other provinces than the effect other provinces have on them. These estimates imply a dynamic that differs somewhat from the view expressed by those who fear inter-provincial competition in labor standards. Our estimates indicate that coastal provinces have less incentive to behave in this manner than do interior provinces; coastal provinces are less likely to lose investment to other provinces when their own wages rise (due to lower own elasticities in coastal provinces) or when inland provinces lower their wages (due to very low cross elasticities of inland provinces). However, our estimates also imply that these coastal provinces have the largest effect on other province's chances of attracting investment if they do attempt to keep wages low.

\section{Conclusion}

In developing countries, foreign direct investment is desired as a source of new capital, for employment generation, to increase specialization and access world markets, and for technology transfer. The location choices of foreign investors reflect complex calculations along many dimensions that influence business costs. Using the control-function approach to control for unobserved attributes of potential hosts, we find evidence that local wages do play a significant role in these considerations. There are important differences in firm behavior, however, consistent with the existence of informal production networks and connections to particular regions. ECE investors, in contrast to OECD investors, are less influenced by wage differences across provinces. They also place greater weight on previous investment, much of it from ECE sources. For both groups, the response to wage differences depends on the capital intensity of the venture.

Recent wage increases in coastal Chinese provinces appear to promise a larger share of FDI for inland provinces. It is often presumed that labor intensive industries will be attracted to the lower wage interior. $^{32}$ Our estimates provide strong support for the presumption that factor intensity matters, but we do not find that the most labor intensive industries are the most responsive to relative wage differences. Because final market demand conditions also influence the location of export processing, we find that investors producing homogenous commodities, such as metals, chemicals, and food processing, are most 
likely to be attracted by lower interior wages. These findings enrich our understanding of multinational behavior by identifying the previously unexamined influence of export-market conditions on FDI-location choice.

To gauge the ability of interior provinces to shift FDI location through regional development policy, we use our estimated coefficients to simulate the effect of a wage subsidy offered only to new firms locating in inland provinces. Following the simulation procedure of Head and Ries (1996), we permit endogenous investment changes to alter the stock of foreign firms and, thus, the agglomeration effect in subsequent years. Provinces in the coastal region, which we assume receives no subsidy, lose investment. However, for a 10 percent wage subsidy in the interior, the flow to each coastal province is diminished by only 6 percent. For inland provinces, a 10 percent wage subsidy increases the flow of foreign investment by 16 to 17 percent. These impacts indicate that regional development policies could lead to substantially larger accumulations of foreign capital in these areas, perhaps contrary to the view that these areas are unattractive to many industries.

Export-processing FDI integrates the host country more deeply into world markets. The ability of firms to pass increases in labor costs forward to these final markets, as may result from enforcement of minimum wages or maximum work hours, shapes the policy space available to local communities seeking better wages and working conditions. Even the perception that labor market regulation will deter foreign investors may lead to weak enforcement by governments and muffled calls for reform from labor organizers. Such a chain of responses fuels fears of a "race to the bottom" in labor standards. ${ }^{33}$ Progress in measuring the response of international investment flows to rising wages in China and other locations is important in addressing these fears. We find separate roles for industrial factor intensity and host country endowments, on the one hand, and export-market demand elasticity, on the other. Explicit acknowledgment of market conditions can also inform analyses of policies that seek to improve labor conditions by altering consumer demand, such as "fair trade" labeling, or the sourcing patterns of producers of final goods, such as "no sweatshop" campaigns. ${ }^{34}$ At a minimum, a focus on export-market conditions helps identify those industries in which such efforts may be useful. Given the large flows of 
direct investment predicted in the wake of the recent global recession, additional research on the links between developed country export markets and developing country labor markets seems warranted. 


\section{Appendix: First Stage Results and Bootstrapping Procedures}

A maintained primitive of the control function approach is that wages are additively separable in

the observed $\left(\mathbf{X}_{j}\right.$ and $\left.Z_{j}\right)$ and the unobserved factors $\left(\xi_{j}\right)$; the unobserved factors are mean independent of the observed factors. This assumption implies uncorrelatedness of unobservables and covariates. It enables use of linear regression in the first stage and ensures the consistent estimation of the residual in the first stage. First stage results are shown in Table A1.

Table A1. First Stage OLS Regression: Dependent Variable is Log Private Wage

\begin{tabular}{lcl}
\hline Variables & Coefficient & $\begin{array}{l}\text { Robust } \\
\text { S.E. }\end{array}$ \\
\hline Constant & 0.788 & 0.862 \\
Log Agglomeration & $0.101^{* * *}$ & 0.011 \\
Log Local Firms & -0.020 & 0.029 \\
Log Population & $-0.121^{* * *}$ & 0.044 \\
Skilled Labor Ratio & $-0.008^{* * *}$ & 0.002 \\
Log Telephone Density & -0.014 & 0.031 \\
Log Private Market Size & $0.111^{* *}$ & 0.052 \\
Squared Log Private Market Size & $-0.022^{* * *}$ & 0.006 \\
Change in State Ownership & -0.284 & 0.279 \\
SEZ or OCC & -0.077 & 0.043 \\
Regional Fixed Effects & & \\
$\quad$ Central & 0.059 & 0.043 \\
$\quad$ Coastal & 0.042 & 0.045 \\
$\quad$ Northeast & -0.000 & 0.041 \\
$\quad$ Northwest & -0.032 & 0.036 \\
Log SOE Wage & $0.846 * * *$ & 0.093 \\
& \multicolumn{2}{c}{196} \\
Number of Observations & \multicolumn{2}{c}{0.86} \\
R ${ }^{2}$ & \multicolumn{2}{c}{} \\
\hline Notes: “***”, “**” and “*” denote significance levels at 1 \\
percent, 5 percent and 10 percent respectively; variables are \\
lagged by one year; Gansu and Tibet excluded.
\end{tabular}

When a control function that includes predicted values is added to the estimation, the coefficients are consistent but the standard errors are incorrect. Petrin and Train (2010) use bootstrapping to correct standard errors in their applications. In the first stage, we bootstrap a wage sample and regress the private wage on the exogenous variables and the instrumental variable, the log of the SOE wage, for years 19901996. ${ }^{35}$ The control function in the second stage is a function of the first stage residual (and the 
interactions of the residual with other covariates when we use interactions of these covariates with wages). We run the conditional logit with this control function and repeat this process 100 times. The variances of these bootstrapped coefficients in the second stage are added to the traditional variance estimates from the conditional logit regression with the control function. ${ }^{36}$ We experiment with different orders of the polynomial of the residuals to specify the control function, but typically, higher orders are insignificant and have only a small effect. 


\section{Endnotes}

1. These wage increases followed suicides at two campuses in Southern China owned by Foxconn Technologies. Foxconn's consideration of inland location for production facilities is reported in "Supply Chain for iPhone Highlights Costs in China," The New York Times, July 5, 2010 $<$ http://www.nytimes.com/2010/07/06/technology/06iphone.html?pagewanted=1\&sq=Foxconn\% 20 Technology\&st $=\operatorname{cse} \& s c p=2>$. This article also reports analysts' perceptions of export processing firms' ability to cope with higher costs.

2. Muendler and Becker (2010) examine the margins of multinational labor substitution and find that employment adjustments are made primarily at the extensive, rather than intensive, margin in a sample of German firms. This evidence highlights the importance of attracting new investment for employment growth.

3. Wang (2001) describes the formal legal system supporting FDI in China and examines the role played by informal personal networks.

4. In the 1995 Industrial Census, no industry received more than 10 percent of total FDI. The geographic distribution of foreign investment within China is highly uneven, as it is in most host countries. Henley et al. (1999) report that 80 percent of cumulative FDI inflows is located in one of China's ten eastern provinces. However, while interior regions received only 13 percent of cumulative FDI from 1992 to 1998, the quantity exceeded all FDI inflows to India during the same period.

5. A recent exception to this pattern is Amiti and Javorcik (2008), who use a different technique. They relate changes in the number of foreign invested firms in Chinese provinces to changes in the average wage.

6. Petrin and Train (2010) provide examples from studies of differentiated product models, including the well known study by Berry, Levinsohn, and Pakes (1995).

7. Further discussion of the application of these methods to modeling firm location decisions can be found in Ondrich and Wasylenko (1993).

8. As Head, Ries, and Swenson (1999) note, this provides a convenient way to capture common attributes. Many studies observe fewer than 1,000 investments and as they sometimes span a decade or more, there are few observations in many year-location cells. Consequently, parsimony is necessary given data limitations.

9. Keller and Levinson (2002) control for time invariant state characteristics in their analysis of the value of foreign owned gross property, plant and equipment but are limited to the use of regional fixed effects in their analysis of planned foreign owned factory openings.

10. During the span of this study, significant restrictions on wholly owned subsidiaries were in place and equity joint ventures were the dominant mode of entry for foreign investors.

11. In 1995, FIEs export sales accounted for about 40 percent of total FIE sales (Huang 2003, Table 1.4), with wide variation by industry and source. This share is an underestimate of the 
importance of foreign markets to FIE sales because it does not include sales of goods that are further processed within China and then re-exported.

12. We condition on the decision to produce in China. We also use a static model of the investment decision, as is common in the literature.

13. An alternative to the assumption of global market demand is to follow Head, Ries, and Swenson (1999) and assume that demand facing the representative firm locating in province $j$ depends on price, local income $I_{j}$, and an idiosyncratic demand shock: $\ln D_{j}=\eta_{I} \ln I_{j}-\eta_{p} \ln p_{j}+e_{i j}^{d}$. In our empirical work, we test the sensitivity of our results to this alternative form for demand.

14. As in Romer (1994), Rutherford and Tarr (2002) and Broda and Weinstein (2006a), variety is defined by country of origin. See Broda and Weinstein (2006, p. 556-8) for a discussion of the asymmetric CES function and resulting demand functions. Their methodology relies on Feenstra (1994).

15. An alternative approach is to use count data with a Poisson or negative binomial specification. These count data approaches are appropriate when there is a preponderance of zeroes and small values for counts (Greene 2003). U.S. data used by Keller and Levinson (2002) have this characteristic but the Chinese data do not.

16. US import elasticity estimates were downloaded from files made available at http://faculty.chicagobooth.edu/christian.broda/website/research/unrestricted/TradeElasticities/Tra deElasticities.html.

17. Grouping of projects into ECE and other foreign is described by Dean, Lovely, and Wang (2009). The ECE designation includes those with a partner from Hong Kong, Macao, Taiwan, Malaysia, Indonesia, and the Philippines, with the first three accounting for 87 percent of the total identified with these countries. Other foreign partners are those from other sources, primarily OECD countries, with the largest shares from the US and Japan. There is no source for 12 percent of projects in 1996, 17 percent in 1995, 10 percent in 1994, and 3 percent in 1993. Since most FDI inflows at this time were ECE, these projects were designated ECE. Because Malaysia, Indonesia, and the Philippines have large ethnically Chinese populations, the few projects from these countries are also included in the ECE subsample. Our results are not sensitive to either inclusion.

18. This discussion adapts the discussion of consumers' choice among differentiated products in Petrin and Train (2010) to the location-choice context.

19. In China, SOE wages prior to 1996 were largely determined by the central government, despite several rounds of wage reforms. Starting in 1985, the Ministry of Labor (MOL) provided some incentives to SOEs, but to a very limited extent. Deeper reforms of China's SOE wage structure were not implemented until the Ninth Five Year Plan (1996-2000). Therefore, during the span of our sample, SOE wages were largely set by central government guidelines and were largely unresponsive to changes in private sector productivity. Evidence from SOE productivity-wage gaps also supports the view that SOE wages do not reflect local attributes that influence firm productivity. Parker (1995) finds that, "In 1992, state industrial wages were 43 percent higher than those available in urban collectives, and only 22 percent below those of the other ownership 
forms; these workers in other ownership forms, however, were 130 percent (in 1990 prices) to 200 percent (in 1980 prices) more productive than those under state ownership."

20. More recent samples of new foreign investment projects, distinguished by location, industry and source country, do not exist. Amiti and Javorcik (2008) examine the role of trade costs in the location of foreign firms, using data from 1998-2001. Their data are drawn from the Annual Survey of Industrial Firms, collected by China's National Bureau of Statistics, for firms with sales above 5 million RMB. They estimate the number of new foreign firms entering each year by comparing year to year foreign firm counts. While this approach has some advantages, including broad coverage, it misses new entrants with sales below the cut off level, it treats firms moving above scale as new entrants, and it cannot distinguish inflows from net flows.

21. Equity joint ventures are limited liability companies incorporated in China, in which foreign and Mainland Chinese investors hold equity. For further details, see Fung (1997). Wang (2001) provides additional details on the legal framework for foreign investment.

22. Coastal: Beijing, Fujian, Guangdong, Hainan, Hebei, Jiangsu, Shandong, Shanghai, Tianjin, Zhejiang; Northeast: Heilongjiang, Jilin, Liaoning; Central: Anhui, Henan, Hubei, Hunan, Jiangxi, Shanxi; Northwest: Gansu, Inner Mongolia, Ningxia, Qinghai, Shaanxi, Tibet, Xinjiang; Southwest: Guangxi, Guizhou, Sichuan, Yunnan.

23. In 1992 China removed many sectoral and regional FDI restrictions (Lardy 1994).

24. The investment percentage is calculated by authors from Huang (2003), Table 1.1. The export share is taken from Huang (2003), p. 18.

25. See sales and export shares by industry in Huang (2003), Table 1.4, page 24.

26. Banister (2005) discusses problems in Chinese labor statistics of geographic coverage, non-wage compensation, and under-reporting,

27. While we expect that a larger local market will attract foreign investors producing for local consumption, in the presence of regional fixed effects we do not have strong priors for the coefficients for $\log$ private market size and its square. Estimates suggest a U-shaped relation between $\log$ private market size and the probability of its being chosen.

28. Huang (2003, p. 40, n. 67) documents the greater clustering of ECE funded ventures, which are less evenly distributed across provinces than is investment from Japan and the United States. Expectations of favors based on local business connections of ECE investors are supported by extensive interviews summarized in Wang (2001).

29. One may wonder if the inclusion of the control function leads to the insignificant interaction term. Unreported estimates, performed without inclusion of the control function, produce coefficients for the wage-capital intensity interaction that are significant at the $10 \%$ level for the full and OECD samples only. These estimates are available from the authors upon request.

30. In unreported regressions, we substituted the Broda-Greenfield-Weinstein (2006b) estimates of China's import demand elasticity for the U.S. elasticity of substitution. These results indicate no significant relationship between the wage sensitivity of foreign investors and Chinese domestic 
market conditions. Given that on average foreign invested enterprises export more than half of their output, this result is not surprising.

31. Dean and Lovely (2010) provide Chinese export shares for 2005 and 1995.

32. This logic appears in numerous articles in the business press, including The Economist, Economic Focus, June 12, 2010, p. 86.

33. The case for a "race to the bottom" in labor standards is developed by Chan (2003).

34. Harrison and Scorse (2010) find that anti-sweatshop activity targeted at specific final goods producers led to large wage gains and limited job losses at Indonesian contract manufacturers in the textile, footwear, and apparel sectors.

35. We do not use years after 1996 in the first stage to avoid possible structural changes in wage structure after 1996 due to SOE reforms. We also do not use years before 1990 for similar concerns. Years after 1989 and before 1993 are kept to increase the sample size and the reliability of bootstrapping. However, the direction and magnitude of bias is consistent when we experiment with different years in the first stage.

36. Karaca-Mandic and Train (2003) propose alternative standard error correction procedures, but find results very similar to bootstrapping. 


\section{References}

Amiti, Mary, and Beata Smarzynska Javorcki. 2008. "Trade Costs and the Location of Foreign Firms in China." Journal of Development Economics 85:129-149.

Banister, Judith. 2005. "Manufacturing Employment and Compensation in China." Working Paper, Beijing Javelin Investment Consulting Company.

Berry, Steven. 1994. "Estimating Discrete Choice Models of Product Differentiation." RAND Journal of Economics 25: 242-262.

Berry, Steven, James Levinsohn, and Ariel Pakes. 1995. "Automobile Prices in Market Equilibrium.” Econometrica 63: 841-890.

Blonigen, Bruce A., Miao G. Wang. 2005. "Inappropriate Pooling of Wealthy and Poor Countries in Empirical FDI Studies.” In: T. Moran, E. Graham, and M. Blomstrom (eds.), Does Foreign Direct Investment Promote Development? Institute for International Economics: Washington, D.C., p. 221-243.

Branstetter, Lee, and Robert C. Feenstra. 2002. "Trade and Foreign Direct Investment in China: a Political Economy Approach.” Journal of International Economics 57: 335-358.

Broda, Christian, and David E. Weinstein. 2006a. "Globalization and the Gains from Variety." Quarterly Journal of Economics 121:541-585.

Broda, Christian, Joshua Greenfield and David Weinstein. 2006b. "From Groundnuts to Globalization: A Structural Estimate of Trade and Growth” NBER Working Paper No. 12512, Sept. 2006.

Chan, Anita. 2003. "A Race to the Bottom." China Perspective 46: 41-49.

Chen, Maggie Xiaoyang, and Michael O. Moore. 2010. "Location Decision of Heterogeneous Multinational Firms.” Journal of International Economics 80: 188-199.

Cheng, Leonard K., and Yum K. Kwan. 2000. "What are the Determinants of the Location of Foreign Direct Investment? The Chinese Experience.” Journal of International Economics 51: 370-400.

Coughlin, Cletus C., and Eran Segev. 2000. "Foreign Direct Investment in China: A Spatial Econometric Study." The World Economy 23: 1-23.

Dean, Judith M. and Mary E. Lovely. 2010. "Trade Growth, Production Fragmentation, and China's Environment.” In R.C. Feenstra and S-J. Wei (eds.), China’s Growing Role in World Trade. Chicago: University of Chicago Press.

Dean, Judith M., Mary E. Lovely, and Hua Wang. 2009. “Are Foreign Investors Attracted to Weak Environmental Regulations? Evaluating the Evidence from China.” Journal of Development Economics, 90(1): 1-13.

Devereux, Michael, and Rachel Griffith. 1998. "Taxes and the Location of Production: Evidence from a Panel of U.S. Multinationals." Journal of Public Economics 68: 1-23. 
Dixit, Avinash and Joseph Stiglitz. 1977. "Monopolistic Competition and Optimum Product Diversity." American Economic Review 67: 297-308.

Feenstra, Robert C. 1994. "New Product Varieties and the Measurement of International Prices." American Economic Review 84:157-177.

Fung, K.C. 1997. Trade and Investment: Mainland China, Hong Kong, and Taiwan. Hong Kong: City University of Hong Kong Press.

Fung, K.C., Hitomi Iizaka, and Stephen Parker. 2002. "Determinants of U.S. and Japanese Direct Investment in China." Journal of Comparative Economics 30: 567-578.

Fung, K.C., Hitomi Iizaka, and Alan Siu. 2003. "Japanese Direct Investment in China." China Economic Review 14: 304-315.

Fung, K.C., Hitomi Iizaka, Chelsea Lin, and Alan Siu. 2005. "An Econometric Estimation of Locational Choices of Foreign Direct Investment: The Case of Hong Kong and U.S. Firms in China," In Y.K. Kwan and E.S.H. Yu (eds.), Critical Issues in Chinese Growth and Development, Conference Volume in Honor of Gregory Chow.

Gao, Ting. 2005. "Labor Quality and the Location of Foreign Direct Investment: Evidence from FDI in China by Investing Country." China Economic Review 16: 274-292.

Greene, William H. 2003. Econometric Analysis. NY: Prentice Hall.

Harrison, Ann, and Jason Scorse. 2010. "Multinationals and Anti-Sweatshop Activism." American Economic Review 100: 247-273.

Head, Keith and Thierry Mayer. 2004. "Market Potential and the Location of Japanese Investment in the European Union." The Review of Economics and Statistics 864: 959-972.

Head, Keith, and John Ries. 1996. "Inter-City Competition for Foreign Investment: Static and Dynamic Effects of China's Incentive Areas.” Journal of Urban Economics 40: 38-60.

Head, Keith, John Ries, and Deborah Swenson. 1999. "Attracting Foreign Manufacturing: Investment Promotion and Agglomeration." Regional Science and Urban Economics 29: 197-218.

Heckman, James. 1976. "The Common Structure of Statistical Models of Truncation, Sample Selection and Limited Dependent Variables and a Simple Estimator for Such Models." Annals of Economic and Social Measurement 5: 475-492.

Heckman, James. 1979. “Sample Selection Bias as a Specification Error.” Econometrica 47: 153-162.

Henley, John, Colin Kirkpatrick, and Georgina Wilde. 1999. "Foreign Direct Investment in China: Recent Trends and Current Policy Issues." World Economy 22: 223-243.

Huang, Yasheng. 2003. Selling China: Foreign Investment during the Reform Era. Cambridge, UK: Cambridge University Press. 
Karaca-Mandic, Pinar and Kenneth Train. 2003. "Standard Error Correction in Two-Stage Estimation with Nested Samples.” Econometrics Journal 62: 401-7.

Keller, Wolfgang and Arik Levinson. 2002. "Pollution Abatement Costs and Foreign Direct Investment Inflows to the United States.” Review of Economics and Statistic 84: 691-703.

Kim, Kyoo il, and Amil Petrin. 2010a. "Control Function Corrections for Unobserved Factors in Differentiated Product Models." University of Minnesota, mimeograph.

Kim, Kyoo il, and Amil Petrin. 2010b. "Tests for Price Endogeneity in Differentiated Product Models." University of Minnesota, mimeograph.

Lardy, Nicholas R., 1994. China in the World Economy. Washington, DC: Institute for International Economics.

List, John A., and Catherine Y. Co. 2000. "The Effects of Environmental Regulations on Foreign Direct Investment." Journal of Environmental Economics and Management 40: 1-20.

Liu, Xuepeng, Mary E. Lovely, and Jan Ondrich. 2010. "The Location Decisions of Foreign Investors in China: Untangling the Effect of Wages Using a Control Function Approach." The Review of Economics and Statistics, 92: 160-166.

Muendler, Marc-Andreas and Sascha O Becker. 2010. "Margins of Multinational Labor Substitution." American Economic Review, 100: 1999-2030.

Ondrich, Jan, and Michael Wasylenko. 1993. Foreign Direct Investment in the United States. Kalamazoo, Michigan: W.E. Upjohn Institute for Employment Research.

Parker, Eliott. 1995. "Prospects for the State-Owned Enterprise in China's Socialist Market Economy." Asian Perspective 19: 7-35.

Petrin, Amil, and Kenneth Train. 2010. "A Control Function Approach to Endogeneity in Consumer Choice Models." Journal of Marketing Research 47: 3-13.

Rauch, James, 1999. "Networks versus Markets in International Trade.” Journal of International Economics 48: 7-35.

Rivers, Douglas, and Quang H. Vuong. 1988. "Limited Information Estimators and Exogeneity Tests for Simultaneous Probit Models.” Journal of Econometrics 39: 347-366.

Romer, Paul. 1994. "New Goods, Old Theory, and the Welfare Costs of Trade Restrictions." Journal of Development Economics 63: 5-38.

Rutherford, Thomas, and David Tarr. 2002. "Trade Liberalization, Product Variety and Growth in a Small Open Economy: A Quantitative Assessment.” Journal of International Economics 56: 247-272.

Smith Richard J. and Richard W. Blundell. 1986. "An Exogeneity Test for a Simultaneous Equation Tobit Model with an Application to Labor Supply.” Econometrica 54: 679-686.

Wang, Hongying. 2001. Weak State, Strong Networks. New York: Oxford University Press. 
Figure 1: Average private wage and average SOE wage, by province, 1992-1995

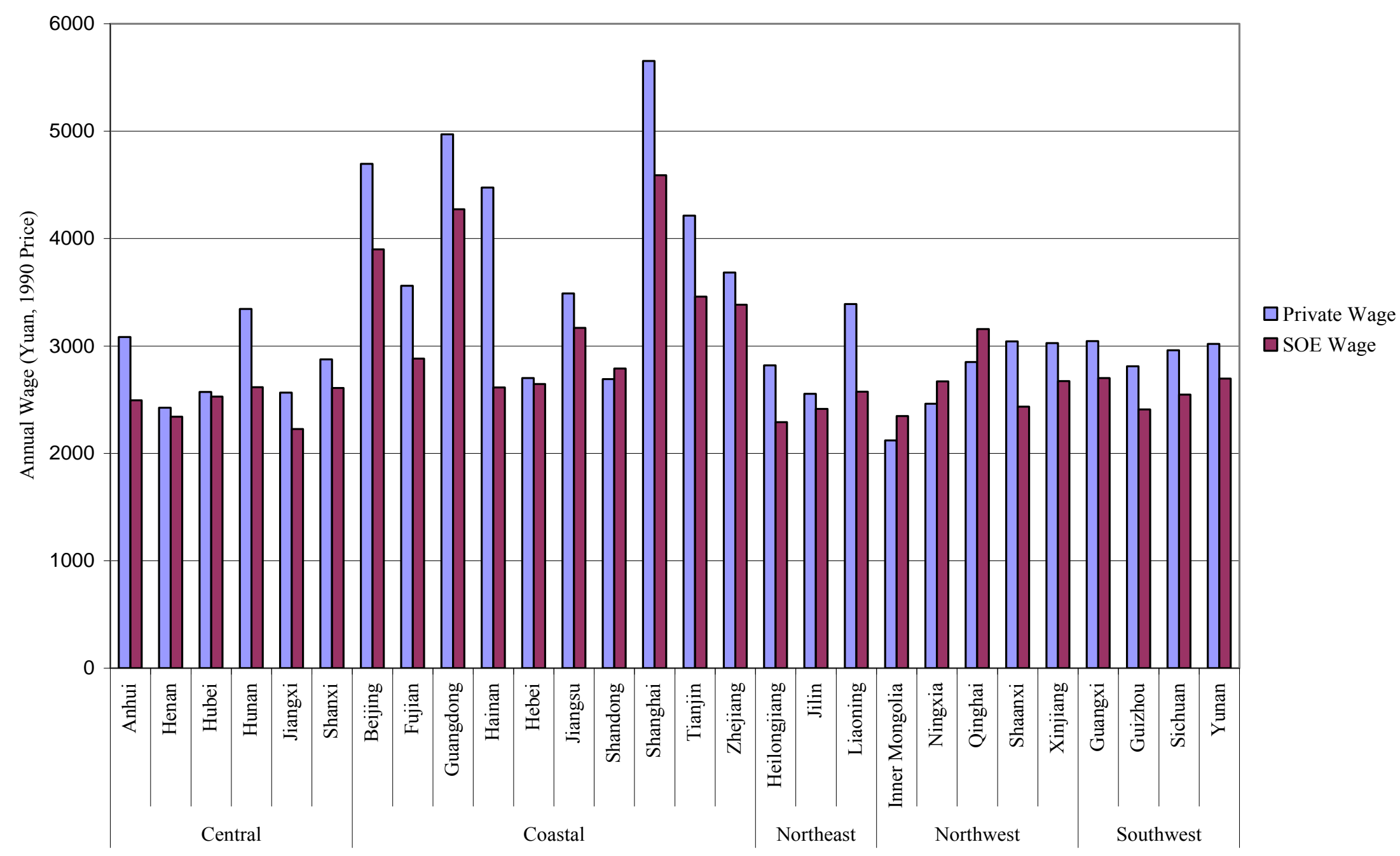

Source: See Table 1. 
Table 1. Data Definitions and Sources

\begin{tabular}{|c|c|c|c|}
\hline Variable & Definition & Source & Mean* \\
\hline \multicolumn{4}{|l|}{ EJV project: } \\
\hline Location & Province & Almanac of China's Foreign Economic Relations & \\
\hline \multirow[t]{2}{*}{ Source } & ECE=Macao, Taiwan, Hong Kong, other South Asian countries & and Trade, various years, & \\
\hline & $\mathrm{OECD}=$ all other countries & Dean, Lovely, and Wang (2009) & \\
\hline Industry & 3-digit ISIC Rev.2 classification & & \\
\hline SOE Wage & $\begin{array}{l}\text { Average annual wage for industrial workers in state owned enterprises, in } \\
1990 \text { yuan, by province }\end{array}$ & $\begin{array}{l}\text { Branstetter and Feenstra (2002), from } \\
\text { China Statistical Yearbook, various years }\end{array}$ & 2837 \\
\hline Private Wage & $\begin{array}{l}\text { Average annual wage for industrial workers in other enterprises (private, } \\
\text { foreign, etc), in } 1990 \text { yuan, by province }\end{array}$ & $\begin{array}{l}\text { Branstetter and Feenstra (2002), from } \\
\text { China Statistical Yearbook, various years }\end{array}$ & 3254 \\
\hline Capital Intensity & $\begin{array}{l}\text { Average annual wage calculated as total industrial wage payment divided } \\
\text { by total industrial employment, concorded to ISIC 3-digit classification }\end{array}$ & China Industrial Census, 1995 & 6175 \\
\hline U.S. Elasticity of & U.S. elasticity of substitution across import varieties, estimated using & Broda and Weinstein (2006a) & 3.88 \\
\hline Substitution & $\begin{array}{l}\text { 1990-2001 data, concorded by authors from SITC Rev. } 3 \text { to ISIC Rev. } 2 \\
\text { classification }\end{array}$ & & \\
\hline Agglomeration & $\begin{array}{l}\text { Cumulative value of real contracted FDI, from } 1983 \text { until } t \text { - } 1 \text {, in millions } \\
\text { of } 1980 \text { U.S. dollars }\end{array}$ & Coughlin, et al. (2000) & 1536 \\
\hline Local Firms & $\begin{array}{l}\text { Number of SOE and collective industrial enterprises at the township level } \\
\text { and above, by province }\end{array}$ & $\begin{array}{l}\text { China Statistical Yearbook, various years, } \\
\text { Dean, Lovely, and Wang (2009) }\end{array}$ & 16061 \\
\hline Population & Population, in millions, by province & China Statistical Yearbook, various years & 41 \\
\hline Skilled Labor Ratio & $\begin{array}{l}\text { Share of population who have a senior secondary school education level or } \\
\text { above (in percentage points), by province }\end{array}$ & $\begin{array}{l}\text { China Statistical Yearbook, various years and } \\
\text { calculations by authors }\end{array}$ & 12.08 \\
\hline Telephone Density & Number of urban telephone subscribers per million persons, by province & China Statistical Yearbook, various years & 29266 \\
\hline Private Market Size & $\begin{array}{l}\text { Real Provincial GDP x (1-SOE share), where SOE share is the production } \\
\text { share of SOEs; GDP is value in billions of } 1990 \text { yuan }\end{array}$ & $\begin{array}{l}\text { China Statistical Yearbook, various years, and } \\
\text { calculations by authors }\end{array}$ & 57 \\
\hline $\begin{array}{l}\text { Change in State } \\
\text { Ownership }\end{array}$ & $\begin{array}{l}\text { Difference between shares of industrial output from SOEs in year } t \text { and } t \text { - } \\
1 \text {, by province }\end{array}$ & $\begin{array}{l}\text { China Statistical Yearbook, various years, } \\
\text { Dean, Lovely, and Wang (2009) }\end{array}$ & -0.04 \\
\hline SEZ or OCC & Dummy variable for a province with SEZ or Open Coastal City & Dean, Lovely, and Wang (2009) & 0.43 \\
\hline
\end{tabular}

*Descriptive statistics for provincial characteristics calculated from pooled data for 1993-1996 (excluding Tibet and Gansu). 
Table 2. Provincial Characteristics, Period Averages (1993-1996)

\begin{tabular}{|c|c|c|c|c|c|c|c|c|}
\hline & $\begin{array}{l}\text { Annual } \\
\text { Private } \\
\text { Wage } \\
(1990 \\
\text { yuan) }\end{array}$ & $\begin{array}{l}\text { Cumulative } \\
\text { FDI } \\
\text { (million } \\
\text { 1980 } \\
\text { US\$) }\end{array}$ & $\begin{array}{l}\text { Number } \\
\text { of local } \\
\text { firms }\end{array}$ & $\begin{array}{l}\text { Population } \\
\text { (millions) }\end{array}$ & $\begin{array}{l}\text { Share of } \\
\text { Skilled } \\
\text { Workers }\end{array}$ & $\begin{array}{l}\text { Phones } \\
\text { per } \\
\text { million } \\
\text { persons }\end{array}$ & $\begin{array}{l}\text { Output } \\
\text { Share } \\
\text { of } \\
\text { SOEs }\end{array}$ & $\begin{array}{l}\text { Private } \\
\text { Market } \\
\text { Size } \\
\text { (billion } \\
1990 \\
\text { yuan) }\end{array}$ \\
\hline Anhui & 3083 & 353 & 23000 & 59 & 7 & 13000 & 0.41 & 53 \\
\hline Beijing & 4695 & 1981 & 7000 & 11 & 32 & 119000 & 0.51 & 34 \\
\hline Fujian & 3561 & 4499 & 12000 & 32 & 8 & 28000 & 0.23 & 73 \\
\hline Guangdong & 4970 & 13876 & 25000 & 67 & 11 & 47000 & 0.25 & 192 \\
\hline Guangxi & 3045 & 933 & 11000 & 45 & 8 & 12000 & 0.50 & 37 \\
\hline Guizhou & 2810 & 87 & 6000 & 34 & 6 & 6000 & 0.71 & 10 \\
\hline Hainan & 4476 & 1336 & 1000 & 7 & 12 & 26000 & 0.53 & 9 \\
\hline Hebei & 2701 & 566 & 21000 & 64 & 8 & 18000 & 0.38 & 82 \\
\hline Heilongiiang & 2819 & 434 & 17000 & 37 & 15 & 30000 & 0.72 & 28 \\
\hline Henan & 2426 & 450 & 20000 & 90 & 8 & 10000 & 0.40 & 83 \\
\hline Hubei & 2574 & 704 & 23000 & 57 & 10 & 17000 & 0.49 & 58 \\
\hline Hunan & 3346 & 475 & 23000 & 63 & 9 & 15000 & 0.48 & 54 \\
\hline Inner Mongolia & 2122 & 78 & 9000 & 22 & 13 & 22000 & 0.68 & 13 \\
\hline Jiangsu & 3489 & 4273 & 39000 & 70 & 12 & 27000 & 0.23 & 184 \\
\hline Jiangxi & 2565 & 293 & 16000 & 40 & 8 & 12000 & 0.50 & 29 \\
\hline Jilin & 2553 & 333 & 13000 & 26 & 17 & 33000 & 0.65 & 20 \\
\hline Liaoning & 3390 & 2064 & 26000 & 41 & 14 & 37000 & 0.49 & 75 \\
\hline Ningxia & 2462 & 11 & 2000 & 5 & 11 & 22000 & 0.74 & 2 \\
\hline Qinghai & 2850 & 5 & 1000 & 5 & 11 & 17000 & 0.83 & 1 \\
\hline Shaanxi & 3042 & 483 & 13000 & 35 & 12 & 14000 & 0.61 & 20 \\
\hline Shandong & 2691 & 2929 & 25000 & 87 & 9 & 16000 & 0.30 & 160 \\
\hline Shanghai & 5654 & 3514 & 9000 & 14 & 29 & 124000 & 0.46 & 65 \\
\hline Shanxi & 2876 & 107 & 11000 & 30 & 12 & 17000 & 0.49 & 27 \\
\hline Sichuan & 2960 & 759 & 37000 & 112 & 7 & 10000 & 0.44 & 94 \\
\hline Tianjin & 4213 & 1039 & 8000 & 9 & 22 & 65000 & 0.41 & 26 \\
\hline Xinjiang & 3027 & 64 & 6000 & 16 & 14 & 20000 & 0.71 & 12 \\
\hline Yunnan & 3021 & 113 & 7000 & 39 & 5 & 11000 & 0.73 & 16 \\
\hline Zhejiang & 3684 & 1251 & 36000 & 43 & 9 & 32000 & 0.19 & 127 \\
\hline
\end{tabular}


Table 3. Multinomial Logit Estimates of Location Choice, by Model and Sample

\begin{tabular}{|c|c|c|c|c|c|c|}
\hline & \multicolumn{3}{|c|}{ With Control Functions } & \multicolumn{3}{|c|}{ Without Control Functions } \\
\hline & $\begin{array}{c}\text { Full } \\
\text { Sample }\end{array}$ & $\begin{array}{c}\text { ECE } \\
\text { Subsample }\end{array}$ & $\begin{array}{c}\text { OECD } \\
\text { Subsample }\end{array}$ & $\begin{array}{c}\text { Full } \\
\text { Sample }\end{array}$ & $\begin{array}{c}\text { ECE } \\
\text { Subsample }\end{array}$ & $\begin{array}{c}\text { OECD } \\
\text { Subsample }\end{array}$ \\
\hline Log Private Wage & $\begin{array}{l}-2.079 * * * \\
(0.462)\end{array}$ & $\begin{array}{l}-1.716^{* * *} \\
(0.598)\end{array}$ & $\begin{array}{l}-2.944 * * * \\
(0.653)\end{array}$ & $\begin{array}{r}-0.949 * * * \\
(0.195)\end{array}$ & $\begin{array}{c}-0.659 * * * \\
(0.251)\end{array}$ & $\begin{array}{c}-1.790^{* * * *} \\
(0.318)\end{array}$ \\
\hline Log Agglomeration & $\begin{array}{l}0.459 * * * \\
(0.075)\end{array}$ & $\begin{array}{l}0.522 * * * \\
(0.090)\end{array}$ & $\begin{array}{l}0.298 * * * \\
(0.114)\end{array}$ & $\begin{array}{c}0.323 * * * \\
(0.050)\end{array}$ & $\begin{array}{c}0.400 * * * \\
(0.063)\end{array}$ & $\begin{array}{c}0.141 \\
(0.086)\end{array}$ \\
\hline Log Local Firms & $\begin{array}{l}0.956 * * * \\
(0.121)\end{array}$ & $\begin{array}{l}0.827 * * * \\
(0.148)\end{array}$ & $\begin{array}{l}1.173 * * * \\
(0.194)\end{array}$ & $\begin{array}{c}1.069 * * * \\
(0.108)\end{array}$ & $\begin{array}{c}0.918 * * * \\
(0.138)\end{array}$ & $\begin{array}{c}1.319 * * * \\
(0.177)\end{array}$ \\
\hline Log Population & $\begin{array}{l}1.675^{* * * *} \\
(0.185)\end{array}$ & $\begin{array}{l}1.798^{* * *} \\
(0.234)\end{array}$ & $\begin{array}{l}1.418^{* * * *} \\
(0.280)\end{array}$ & $\begin{array}{c}1.757^{* * *} \\
(0.163)\end{array}$ & $\begin{array}{c}1.838^{* * * *} \\
(0.215)\end{array}$ & $\begin{array}{c}1.583 * * * \\
(0.258)\end{array}$ \\
\hline Skilled Labor Ratio & $\begin{array}{l}0.104^{* * * *} \\
(0.011)\end{array}$ & $\begin{array}{l}0.074 * * * \\
(0.013)\end{array}$ & $\begin{array}{l}0.150^{* * * *} \\
(0.016)\end{array}$ & $\begin{array}{c}0.117 * * * \\
(0.008)\end{array}$ & $\begin{array}{c}0.087 * * * \\
(0.010)\end{array}$ & $\begin{array}{c}0.165 * * * \\
(0.013)\end{array}$ \\
\hline Log Telephone Density & $\begin{array}{l}0.570 * * * \\
(0.151)\end{array}$ & $\begin{array}{l}0.621 * * * \\
(0.205)\end{array}$ & $\begin{array}{l}0.572 * * * \\
(0.200)\end{array}$ & $\begin{array}{c}0.338 * * * \\
(0.109)\end{array}$ & $\begin{array}{c}0.376^{* * *} \\
(0.143)\end{array}$ & $\begin{array}{c}0.399 * * \\
(0.173)\end{array}$ \\
\hline Log Private Market Size & $\begin{array}{l}-2.881 * * * \\
(0.268)\end{array}$ & $\begin{array}{l}-2.646^{* * * *} \\
(0.346)\end{array}$ & $\begin{array}{l}-3.127 * * * \\
(0.409)\end{array}$ & $\begin{array}{c}-2.936^{* * *} \\
(0.255)\end{array}$ & $\begin{array}{c}-2.687 * * * \\
(0.333)\end{array}$ & $\begin{array}{c}-3.203 * * * \\
(0.395)\end{array}$ \\
\hline Squared Log Private Market Size & $\begin{array}{l}0.193 * * * \\
(0.026)\end{array}$ & $\begin{array}{l}0.152 * * * \\
(0.035)\end{array}$ & $\begin{array}{l}0.261 * * * \\
(0.037)\end{array}$ & $\begin{array}{c}0.204 * * * \\
(0.024)\end{array}$ & $\begin{array}{c}0.164 * * * \\
(0.032)\end{array}$ & $\begin{array}{c}0.270 * * * \\
(0.035)\end{array}$ \\
\hline Change in State Ownership & $\begin{array}{l}-5.908^{* * * *} \\
(1.033)\end{array}$ & $\begin{array}{l}-6.387 * * * \\
(1.285)\end{array}$ & $\begin{array}{l}-5.853 * * * \\
(1.381)\end{array}$ & $\begin{array}{c}-5.383 * * * \\
(0.823)\end{array}$ & $\begin{array}{c}-5.881 * * * \\
(1.112)\end{array}$ & $\begin{array}{c}-5.370 * * * \\
(1.251)\end{array}$ \\
\hline SEZ or OCC & $\begin{array}{l}1.195 * * * \\
(0.168)\end{array}$ & $\begin{array}{l}0.827 * * * \\
(0.203)\end{array}$ & $\begin{array}{l}1.638 * * * \\
(0.243)\end{array}$ & $\begin{array}{c}1.344 * * * \\
(0.139)\end{array}$ & $\begin{array}{c}0.933 * * * \\
(0.189)\end{array}$ & $\begin{array}{c}1.850 * * * \\
(0.210)\end{array}$ \\
\hline Regional Fixed Effects & & & & & & \\
\hline Central & $\begin{array}{l}1.595 * * * \\
(0.166)\end{array}$ & $\begin{array}{l}1.632 * * * \\
(0.198)\end{array}$ & $\begin{array}{l}1.345^{* * *} \\
(0.272)\end{array}$ & $\begin{array}{c}1.618 * * * \\
(0.158)\end{array}$ & $\begin{array}{c}1.645 * * * \\
(0.194)\end{array}$ & $\begin{array}{c}1.359 * * * \\
(0.269)\end{array}$ \\
\hline Coastal & $\begin{array}{l}1.687 * * * \\
(0.186)\end{array}$ & $\begin{array}{l}1.920 * * * \\
(0.236)\end{array}$ & $\begin{array}{l}1.251 * * * \\
(0.296)\end{array}$ & $\begin{array}{c}1.723 * * * \\
(0.174)\end{array}$ & $\begin{array}{c}1.971 * * * \\
(0.223)\end{array}$ & $\begin{array}{c}1.230 * * * \\
(0.288)\end{array}$ \\
\hline Northeast & $\begin{array}{l}0.678 * * * \\
(0.201)\end{array}$ & $\begin{array}{l}0.616^{* *} \\
(0.263)\end{array}$ & $\begin{array}{l}0.614 * * \\
(0.304)\end{array}$ & $\begin{array}{c}0.991 * * * \\
(0.162)\end{array}$ & $\begin{array}{c}0.910 * * * \\
(0.208)\end{array}$ & $\begin{array}{c}0.906 * * * \\
(0.265)\end{array}$ \\
\hline Northwest & $\begin{array}{l}0.163 \\
(0.227)\end{array}$ & $\begin{array}{l}-0.037 \\
(0.301)\end{array}$ & $\begin{array}{l}0.257 \\
(0.352)\end{array}$ & $\begin{array}{c}0.325 \\
(0.213)\end{array}$ & $\begin{array}{c}0.103 \\
(0.282)\end{array}$ & $\begin{array}{c}0.435 \\
(0.340)\end{array}$ \\
\hline Residual & $\begin{array}{l}1.721^{* * * *} \\
(0.614)\end{array}$ & $\begin{array}{l}1.518 * * \\
(0.763)\end{array}$ & $\begin{array}{l}1.914 * * \\
(0.922)\end{array}$ & & & \\
\hline Number of Observations & 2884 & 1711 & 1173 & 2884 & 1711 & 1173 \\
\hline Pseudo $\mathrm{R}^{2}$ & 0.183 & 0.182 & 0.203 & 0.182 & 0.181 & 0.202 \\
\hline Log-Likelihood & -7854.583 & -4663.425 & -3115.200 & -7862.422 & -4666.986 & -3118.752 \\
\hline
\end{tabular}

Notes:

1. All covariates are lagged by one year; Gansu and Tibet are excluded.

2. “***”, “**” and “*” denote significance levels at 1 percent, 5 percent and 10 percent levels, respectively. 
Table 4. Allowing Wage Sensitivity to Vary with Factor Intensity and US Substitution Elasticity, by Model and Sample

\begin{tabular}{|c|c|c|c|c|c|c|}
\hline & \multicolumn{3}{|c|}{ With Control Functions } & \multicolumn{3}{|c|}{ With Control Functions } \\
\hline & $\begin{array}{c}\text { Full } \\
\text { Sample }\end{array}$ & $\begin{array}{c}\text { ECE } \\
\text { Subsample }\end{array}$ & $\begin{array}{c}\text { OECD } \\
\text { Subsample }\end{array}$ & $\begin{array}{c}\text { Full } \\
\text { Sample }\end{array}$ & $\begin{array}{c}\text { ECE } \\
\text { Subsample }\end{array}$ & $\begin{array}{c}\text { OECD } \\
\text { Subsample }\end{array}$ \\
\hline Log Private Wage & $\begin{array}{l}-2.451^{* * *} \\
(0.720)\end{array}$ & $\begin{array}{l}-1.942 * * \\
(0.880)\end{array}$ & $\begin{array}{l}-3.772 * * * \\
(1.114)\end{array}$ & $\begin{array}{l}-3.185^{* * * *} \\
(0.726)\end{array}$ & $\begin{array}{l}-2.793 * * * \\
(0.915)\end{array}$ & $\begin{array}{l}-4.345^{* * * *} \\
(1.157)\end{array}$ \\
\hline Log Private Wage*Capital Intensity & $\begin{array}{l}0.060 \\
(0.090)\end{array}$ & $\begin{array}{l}0.037 \\
(0.114)\end{array}$ & $\begin{array}{l}0.133 \\
(0.143)\end{array}$ & $\begin{array}{l}0.371 * * * \\
(0.106)\end{array}$ & $\begin{array}{l}0.356^{* *} \\
(0.141)\end{array}$ & $\begin{array}{l}0.452 * * * \\
(0.165)\end{array}$ \\
\hline Log Private Wage*Demand Elasticity & & & & $\begin{array}{l}-0.368 * * * \\
(0.069)\end{array}$ & $\begin{array}{l}-0.339 * * * \\
(0.091)\end{array}$ & $\begin{array}{l}-0.431 * * * \\
(0.107)\end{array}$ \\
\hline Log Agglomeration & $\begin{array}{l}0.459 * * * \\
(0.075)\end{array}$ & $\begin{array}{l}0.522 * * * \\
(0.088)\end{array}$ & $\begin{array}{l}0.299 * * * \\
(0.115)\end{array}$ & $\begin{array}{l}0.463 * * * \\
(0.075)\end{array}$ & $\begin{array}{l}0.525^{* * * *} \\
(0.087)\end{array}$ & $\begin{array}{l}0.302^{* * *} \\
(0.115)\end{array}$ \\
\hline Log Local Firms & $\begin{array}{l}0.952 * * * \\
(0.122)\end{array}$ & $\begin{array}{l}0.824 * * * \\
(0.147)\end{array}$ & $\begin{array}{l}1.170 * * * \\
(0.195)\end{array}$ & $\begin{array}{l}0.971^{* * *} \\
(0.121)\end{array}$ & $\begin{array}{l}0.836^{* * *} \\
(0.150)\end{array}$ & $\begin{array}{l}1.208^{* * *} \\
(0.199)\end{array}$ \\
\hline Log Population & $\begin{array}{l}1.676^{* * * *} \\
(0.193)\end{array}$ & $\begin{array}{l}1.799 * * * \\
(0.228)\end{array}$ & $\begin{array}{l}1.423 * * * \\
(0.280)\end{array}$ & $\begin{array}{l}1.670^{* * *} \\
(0.186)\end{array}$ & $\begin{array}{l}1.794 * * * \\
(0.232)\end{array}$ & $\begin{array}{l}1.422 * * * \\
(0.283)\end{array}$ \\
\hline Skilled Labor Ratio & $\begin{array}{l}0.103 * * * \\
(0.011)\end{array}$ & $\begin{array}{l}0.074 * * * \\
(0.013)\end{array}$ & $\begin{array}{l}0.149^{* * *} \\
(0.016)\end{array}$ & $\begin{array}{l}0.104 * * * \\
(0.011)\end{array}$ & $\begin{array}{l}0.075^{* * *} * \\
(0.013)\end{array}$ & $\begin{array}{l}0.151 * * * \\
(0.016)\end{array}$ \\
\hline Log Telephone Density & $\begin{array}{l}0.578 * * * \\
(0.159)\end{array}$ & $\begin{array}{l}0.626 * * * \\
(0.197)\end{array}$ & $\begin{array}{l}0.585^{* * *} \\
(0.202)\end{array}$ & $\begin{array}{l}0.562 * * * \\
(0.152)\end{array}$ & $\begin{array}{l}0.618^{* * * *} \\
(0.190)\end{array}$ & $\begin{array}{l}0.549 * * * \\
(0.208)\end{array}$ \\
\hline Log Private Market Size & $\begin{array}{l}-2.876^{* * * *} \\
(0.273)\end{array}$ & $\begin{array}{l}-2.644 * * * \\
(0.343)\end{array}$ & $\begin{array}{l}-3.129^{* * *} \\
(0.412)\end{array}$ & $\begin{array}{l}-2.911 * * * \\
(0.268)\end{array}$ & $\begin{array}{l}-2.669^{* * * *} \\
(0.345)\end{array}$ & $\begin{array}{l}-3.193^{* * *} \\
(0.410)\end{array}$ \\
\hline Squared Log Private Market Size & $\begin{array}{l}0.193 * * * \\
(0.027)\end{array}$ & $\begin{array}{l}0.152 * * * \\
(0.034)\end{array}$ & $\begin{array}{l}0.261 * * * \\
(0.037)\end{array}$ & $\begin{array}{l}0.196 * * * \\
(0.026)\end{array}$ & $\begin{array}{l}0.154 * * * \\
(0.034)\end{array}$ & $\begin{array}{l}0.266 * * * \\
(0.037)\end{array}$ \\
\hline Change in State Ownership & $\begin{array}{l}-5.915^{* * *} \\
(1.066)\end{array}$ & $\begin{array}{l}-6.383 * * * \\
(1.271)\end{array}$ & $\begin{array}{l}-5.906^{* * * *} \\
(1.396)\end{array}$ & $\begin{array}{l}-5.991 * * * \\
(1.044)\end{array}$ & $\begin{array}{l}-6.437 * * * \\
(1.270)\end{array}$ & $\begin{array}{l}-5.980 * * * \\
(1.427)\end{array}$ \\
\hline SEZ or OCC & $\begin{array}{l}1.190^{* * * *} \\
(0.170)\end{array}$ & $\begin{array}{l}0.824^{* * *} \\
(0.201)\end{array}$ & $\begin{array}{l}1.633^{* * * *} \\
(0.243)\end{array}$ & $\begin{array}{l}1.197 * * * \\
(0.169)\end{array}$ & $\begin{array}{l}0.830^{* * * *} \\
(0.208)\end{array}$ & $\begin{array}{l}1.651^{* * *} \\
(0.250)\end{array}$ \\
\hline Regional Fixed Effects & & & & & & \\
\hline Central & $\begin{array}{l}1.591 * * * \\
(0.167)\end{array}$ & $\begin{array}{l}1.630 * * * \\
(0.199)\end{array}$ & $\begin{array}{l}1.341 * * * \\
(0.272)\end{array}$ & $\begin{array}{l}1.602 * * * \\
(0.167)\end{array}$ & $\begin{array}{l}1.637 * * * \\
(0.201)\end{array}$ & $\begin{array}{l}1.362 * * * \\
(0.275)\end{array}$ \\
\hline Coastal & $\begin{array}{l}1.689 * * * \\
(0.190)\end{array}$ & $\begin{array}{l}1.920 * * * \\
(0.233)\end{array}$ & $\begin{array}{l}1.256 * * * \\
(0.297)\end{array}$ & $\begin{array}{l}1.703 * * * \\
(0.187)\end{array}$ & $\begin{array}{l}1.928 * * * \\
(0.240)\end{array}$ & $\begin{array}{l}1.286^{* * *} \\
(0.299)\end{array}$ \\
\hline Northeast & $\begin{array}{l}0.673 * * * \\
(0.207)\end{array}$ & $\begin{array}{l}0.613^{* *} \\
(0.256)\end{array}$ & $\begin{array}{l}0.606^{* *} \\
(0.306)\end{array}$ & $\begin{array}{l}0.680^{* * *} \\
(0.202)\end{array}$ & $\begin{array}{l}0.614^{* *} \\
(0.254)\end{array}$ & $\begin{array}{l}0.630^{* *} \\
(0.311)\end{array}$ \\
\hline Northwest & $\begin{array}{l}0.162 \\
(0.232)\end{array}$ & $\begin{array}{l}-0.037 \\
(0.297)\end{array}$ & $\begin{array}{l}0.252 \\
(0.353)\end{array}$ & $\begin{array}{c}0.162 \\
(0.229)\end{array}$ & $\begin{array}{l}-0.039 \\
(0.292)\end{array}$ & $\begin{array}{l}0.258 \\
(0.353)\end{array}$ \\
\hline Residual & $\begin{array}{l}-2.839^{*} \\
(1.634)\end{array}$ & $\begin{array}{l}-1.848 \\
(2.057)\end{array}$ & $\begin{array}{l}-3.718 \\
(2.672)\end{array}$ & $\begin{array}{l}-1.880 \\
(1.669)\end{array}$ & $\begin{array}{l}-0.377 \\
(2.198)\end{array}$ & $\begin{array}{l}-3.055 \\
(2.722)\end{array}$ \\
\hline Residual*Capital Intensity & $\begin{array}{l}0.768 * * * \\
(0.251)\end{array}$ & $\begin{array}{l}0.572^{*} \\
(0.334)\end{array}$ & $\begin{array}{l}0.937 * * \\
(0.401)\end{array}$ & $\begin{array}{l}0.398 \\
(0.309)\end{array}$ & $\begin{array}{l}0.046 \\
(0.425)\end{array}$ & $\begin{array}{l}0.642 \\
(0.458)\end{array}$ \\
\hline Residual*Import Demand & & & & $\begin{array}{l}0.411^{* *} \\
(0.193) \\
\end{array}$ & $\begin{array}{l}0.535^{* *} \\
(0.258) \\
\end{array}$ & $\begin{array}{l}0.358 \\
(0.285) \\
\end{array}$ \\
\hline Number of Observations & 2884 & 1711 & 1173 & 2884 & 1711 & 1173 \\
\hline Pseudo $\mathrm{R}^{2}$ & 0.183 & 0.183 & 0.204 & 0.185 & 0.184 & 0.206 \\
\hline Log-Likelihood & -7847.471 & -4661.122 & -3110.259 & -7832.277 & -4653.435 & -3102.665 \\
\hline $\begin{array}{l}\text { CF Wald Statistic } \\
\text { (p-value) }\end{array}$ & $\begin{array}{l}16.93 * * * \\
(0.00021)\end{array}$ & $\begin{array}{l}6.97 * * \\
(0.0307) \\
\end{array}$ & $\begin{array}{l}10.61 * * \\
(0.00497)\end{array}$ & $\begin{array}{c}21.91 * * * \\
(0.000068)\end{array}$ & $\begin{array}{l}10.73 * * \\
(0.013) \\
\end{array}$ & $\begin{array}{l}11.47 * * * \\
(0.0094)\end{array}$ \\
\hline
\end{tabular}

Notes:

1. All covariates are lagged by one year; Gansu and Tibet are excluded.

2. “***”, "***” and “*” denote significance levels at 1 percent, 5 percent and 10 percent levels, respectively. 
Table 5. Average Estimated OwnWage Elasticity, by Industry

\begin{tabular}{llcc|ccc}
\hline & Industry & $\begin{array}{c}\text { Industry } \\
\text { Capital } \\
\text { Intensity }\end{array}$ & $\begin{array}{c}\text { Demand } \\
\text { Elasticity }\end{array}$ & $\begin{array}{c}\text { Fumple } \\
\text { Elasticity }\end{array}$ & $\begin{array}{c}\text { ECE } \\
\text { Sample } \\
\text { Elasticity }\end{array}$ & $\begin{array}{c}\text { OECD } \\
\text { Sample } \\
\text { Elasticity }\end{array}$ \\
\hline 324 & Footwear & 4.29 & 2.41 & -1.99 & -1.69 & -2.70 \\
331 & Wood & 4.51 & 1.95 & -1.81 & -1.52 & -2.50 \\
321 & Textiles & 4.63 & 2.64 & -1.99 & -1.68 & -2.72 \\
390 & Other & 4.80 & 2.27 & -1.83 & -1.53 & -2.52 \\
323 & Leather & 4.81 & 1.77 & -1.67 & -1.39 & -2.35 \\
341 & Paper & 5.22 & 3.16 & -1.94 & -1.64 & -2.64 \\
311 & Food & 5.33 & 3.57 & -2.03 & -1.72 & -2.74 \\
356 & Plastic & 5.41 & 1.69 & -1.47 & -1.19 & -2.10 \\
361 & Pottery & 5.45 & 1.85 & -1.51 & -1.23 & -2.14 \\
322 & Apparel & 5.53 & 3.16 & -1.85 & -1.55 & -2.53 \\
313 & Beverages & 5.57 & 2.45 & -1.64 & -1.35 & -2.28 \\
332 & Furniture & 5.75 & 2.53 & -1.59 & -1.31 & -2.21 \\
381 & Fabricated Metal & 5.76 & 3.03 & -1.75 & -1.45 & -2.40 \\
369 & Mineral & 5.81 & 1.80 & -1.38 & -1.11 & -1.99 \\
355 & Rubber & 5.94 & 2.57 & -1.56 & -1.28 & -2.18 \\
382 & Non-electric Machinery & 6.29 & 3.06 & -1.58 & -1.30 & -2.19 \\
342 & Printing & 6.38 & 3.13 & -1.60 & -1.31 & -2.23 \\
354 & Misc Petroleum and Coal & 6.41 & 2.51 & -1.40 & -1.12 & -2.00 \\
362 & Glass & 6.41 & 1.69 & -1.15 & -0.89 & -1.71 \\
352 & Other Chemicals & 6.43 & 5.07 & -2.12 & -1.80 & -2.82 \\
351 & Industrial Chemicals & 6.52 & 4.83 & -2.02 & -1.70 & -2.70 \\
385 & Professional & 6.57 & 1.83 & -1.16 & -0.89 & -1.72 \\
383 & Electric Machinery & 6.75 & 2.02 & -1.15 & -0.89 & -1.71 \\
384 & Transport & 6.96 & 3.26 & -1.45 & -1.17 & -2.04 \\
372 & Non-ferrous Metals & 7.38 & 6.64 & -2.29 & -1.95 & -3.01 \\
371 & Iron and Steel & 8.27 & 8.54 & -2.55 & -2.18 & -3.29 \\
353 & Petroleum Refineries & 9.88 & 7.16 & -1.67 & -1.35 & -2.24 \\
\hline Dat & Ins & 5.67 &
\end{tabular}

Data sources for capital intensity measure and demand elasticity: see Table 1.

Jiangsu Province is taken as the benchmark province in elasticity calculation; The last three columns are based on the coefficient estimates in the last three columns of Table 4; Industries are sorted by capital intensity. 
Table 6. Estimated Own-Wage and Cross-Wage Probability Elasticities, by Province

\begin{tabular}{|c|c|c|c|c|c|c|}
\hline \multirow[b]{2}{*}{ Provinces } & \multicolumn{2}{|c|}{ Full Sample } & \multicolumn{2}{|c|}{ ECE Sample } & \multicolumn{2}{|c|}{ OECD Sample } \\
\hline & $\begin{array}{c}\text { Own } \\
\text { Elasticity }\end{array}$ & $\begin{array}{c}\text { Cross } \\
\text { Elasticity }\end{array}$ & $\begin{array}{c}\text { Own } \\
\text { Elasticity }\end{array}$ & $\begin{array}{c}\text { Cross } \\
\text { Elasticity }\end{array}$ & $\begin{array}{c}\text { Own } \\
\text { Elasticity }\end{array}$ & $\begin{array}{c}\text { Cross } \\
\text { Elasticity }\end{array}$ \\
\hline Anhui & -2.09 & 0.04 & -1.71 & 0.02 & -2.99 & 0.01 \\
\hline Beijing & -1.96 & 0.17 & -1.67 & 0.06 & -2.87 & 0.13 \\
\hline Fujian & -2.07 & 0.06 & -1.70 & 0.04 & -2.98 & 0.02 \\
\hline Guangdong & -1.86 & 0.27 & -1.57 & 0.17 & -2.91 & 0.10 \\
\hline Guangxi & -2.11 & 0.02 & -1.72 & 0.01 & -2.99 & 0.01 \\
\hline Guizhou & -2.12 & 0.00 & -1.73 & 0.00 & -3.00 & 0.00 \\
\hline Hainan & -2.12 & 0.01 & -1.72 & 0.01 & -3.00 & 0.00 \\
\hline Hebei & -2.00 & 0.13 & -1.67 & 0.06 & -2.93 & 0.08 \\
\hline Heilongjiang & -2.07 & 0.06 & -1.71 & 0.03 & -2.97 & 0.03 \\
\hline Henan & -2.08 & 0.05 & -1.71 & 0.03 & -2.98 & 0.02 \\
\hline Hubei & -2.06 & 0.07 & -1.69 & 0.04 & -2.97 & 0.03 \\
\hline Hunan & -2.08 & 0.05 & -1.70 & 0.03 & -2.98 & 0.02 \\
\hline Inner Mongolia & -2.12 & 0.01 & -1.73 & 0.00 & -2.99 & 0.01 \\
\hline Jiangsu & -1.72 & 0.41 & -1.55 & 0.18 & -2.74 & 0.26 \\
\hline Jiangxi & -2.10 & 0.03 & -1.72 & 0.02 & -2.99 & 0.01 \\
\hline Jilin & -2.09 & 0.04 & -1.72 & 0.02 & -2.97 & 0.03 \\
\hline Liaoning & -2.00 & 0.13 & -1.69 & 0.04 & -2.90 & 0.11 \\
\hline Ningxia & -2.13 & 0.00 & -1.73 & 0.00 & -3.00 & 0.00 \\
\hline Qinghai & -2.13 & 0.00 & -1.73 & 0.00 & -3.00 & 0.00 \\
\hline Shaanxi & -2.11 & 0.02 & -1.73 & 0.01 & -3.00 & 0.01 \\
\hline Shandong & -1.89 & 0.24 & -1.62 & 0.12 & -2.87 & 0.14 \\
\hline Shanghai & -2.03 & 0.10 & -1.70 & 0.04 & -2.94 & 0.07 \\
\hline Shanxi & -2.11 & 0.02 & -1.73 & 0.01 & -3.00 & 0.01 \\
\hline Sichuan & -2.11 & 0.02 & -1.72 & 0.01 & -2.99 & 0.01 \\
\hline Tianjin & -2.07 & 0.06 & -1.71 & 0.02 & -2.97 & 0.04 \\
\hline Xinjiang & -2.13 & 0.00 & -1.73 & 0.00 & -3.00 & 0.00 \\
\hline Yunnan & -2.13 & 0.00 & -1.73 & 0.00 & -3.00 & 0.00 \\
\hline Zhejiang & -2.02 & 0.11 & -1.68 & 0.05 & -2.94 & 0.06 \\
\hline
\end{tabular}

Note: Elasticities based on the coefficient estimates in the last three columns of Table 4 . 